\title{
Subsurface lateral flow from hillslope and its contribution to nitrate loading in streams through an agricultural catchment during subtropical rainstorm events
}

\author{
B. Zhang ${ }^{1,2}$, J. L. Tang ${ }^{2,3}$, Ch. Gao ${ }^{4}$, and H. Zepp ${ }^{5}$ \\ ${ }^{1}$ Key Laboratory of Crop Nutrition and Nutrient Cycling of Ministry of Agriculture of China, Institute of Agricultural \\ Resources and Regional Planning, Chinese Academy of Agricultural Sciences (CAAS), Beijing, 100081, China \\ ${ }^{2}$ Key State Laboratory of Soil and Sustainable Agriculture, Institute of Soil Science, Chinese Academy of Sciences (CAS), \\ Nanjing, 210008, China \\ ${ }^{3}$ Institute of Mountain Hazards and Environment, Chinese Academy of Sciences (CAS), Chengdu, 610041, China \\ ${ }^{4}$ Geographical Institute of Nanjing University, Nanjing, 210093, China \\ ${ }^{5}$ Geographical Institute of Ruhr University, 44780 Bochum, Germany
}

Received: 11 April 2011 - Published in Hydrol. Earth Syst. Sci. Discuss.: 27 April 2011

Revised: 19 September 2011 - Accepted: 3 October 2011 - Published: 18 October 2011

\begin{abstract}
Subsurface lateral flow from agricultural hillslopes is often overlooked compared with overland flow and tile drain flow, partly due to the difficulties in monitoring and quantifying. The objectives of this study were to examine how subsurface lateral flow generated through soil pedons from cropped hillslopes and to quantify its contribution to nitrate loading in the streams through an agricultural catchment in the subtropical region of China. Profiles of soil water potential along hillslopes and stream hydro-chemographs in a trenched stream below a cropped hillslope and at the catchment outlet were simultaneously recorded during two rainstorm events. The dynamics of soil water potential showed positive matrix soil water potential over impermeable soil layer at 0.6 to $1.50 \mathrm{~m}$ depths during and after the storms, indicating soil water saturation and drainage processes along the hillslopes irrespective of land uses. The hydro-chemographs in the streams, one trenched below a cropped hillslope and one at the catchment outlet, showed that the concentrations of particulate nitrogen and phosphorus corresponded well to stream flow during the storm, while the nitrate concentration increased on the recession limbs of the hydrographs after the end of the storm. All the synchronous data revealed that nitrate was delivered from the cropped hillslope through subsurface lateral flow to the streams during and after the end of the rainstorms. A chemical mixing model based on
\end{abstract}

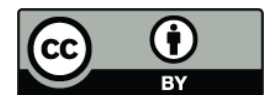

Correspondence to: $\mathrm{B}$. Zhang

(bzhang@caas.ac.cn) electricity conductivity (EC) and $\mathrm{H}^{+}$concentration was successfully established, particularly for the trenched stream. The results showed that the subsurface lateral flow accounted for $29 \%$ to $45 \%$ of total stream flow in the trenched stream, responsible for $86 \%$ of total $\mathrm{NO}_{3}^{-}-\mathrm{N}$ loss (or $26 \%$ of total $\mathrm{N}$ loss), and for $5.7 \%$ to $7.3 \%$ of total stream flow at the catchment outlet, responsible for about $69 \%$ of total $\mathrm{NO}_{3}^{-}-\mathrm{N}$ loss (or $28 \%$ of total $\mathrm{N}$ loss). The results suggest that subsurface lateral flow through hydraulically stratified soil pedons have to be paid more attention for controlling non-point source surface water pollution from intensive agricultural catchment particularly in the subtropical areas with great soil infiltration.

\section{Introduction}

Non-point source of nutrient exports from agricultural fields to surface water and ground water is concerned worldwide (USEPA, 1996). Agriculture in China, for example, consumes more than two thirds of world's total chemical fertilizers (Zhou et al., 2004). It is estimated that the amount of $\mathrm{N}$ delivered annually from agriculture through the Yangtze River, Yellow River and Pearl River to the oceans is as much as 0.97 million tons of $\mathrm{N}$ (Duan et al., 2000). Excess nitrogen in rivers and streams has been linked to the eutrophication of rivers, lakes and coastal waters in China (Huang et al., 1998; Duan et al., 2000; Zhang et al., 2004) and

Published by Copernicus Publications on behalf of the European Geosciences Union. 
blamed for the negative impacts on human and ecosystem health (Wu et al., 1999). Since most of nutrient losses occur during rainfall events, especially in subtropical or tropical area (Kwong et al., 2002; Tang et al., 2008), overland flow is generally considered as the most important hydrological pathway from agricultural lands (Edwards and Owens, 1991; Zhu and Chen, 2002). Overland flow during several rainstorms can deliver more than half (Lowrance et al., 1984; Edwards and Owens, 1991) or even $90 \%$ (Nash and Halliwell, 1999) of total annual losses of soils and nutrients in agricultural catchment. However, controlling overland flow is often less effective than expected in improving surface water quality especially in agricultural catchment.

Subsurface lateral flow can be another important pathway for nutrient transport. This is confirmed by many studies that have illustrated the profound contribution of subsurface lateral pipe flow through the tile drains to the loads of nitrate (e.g. Mohanty et al., 1998; van der Velde et al., 2010), dissolved phosphorous (e.g. Stamm et al., 1998; Sinaj et al., 2002) and pesticides (e.g. Zehe and Flühler, 2001) in many agricultural fields. However, it remains poorly understood whether subsurface lateral flow generates prevalently through soil pedon in agricultural catchment and is important for nutrient delivery to surface water. Lack of such information is partly because of the difficulties in direct monitoring and quantifying subsurface lateral flow compared with overland flow and tile drainage (Allaire et al., 2009). Subsurface lateral flow is generally initiated when rainwater percolates through a soil profile, meets an impeding layer of soil, regolith or bedrock on hillsope, forms saturated condition and then is diverted laterally downslope (Luxmoore, 1991; Newman et al., 1998). Subsurface lateral flow has been intensively studied in natural ecosystems as it is a major hydrological process (Cirmo and McDonnell, 1997; DeWalle et al., 1988; Burns et al., 2001; McHale et al., 2002; Inamdar and Mitchell, 2007) and it is linked to spatial pedogenetic variations of nutrients and pollutants (Schlichting and Schweikle, 1980). In agriculture, soil structure within a soil profile can be altered by natural soil water erosion and by soil tillage. For example, field machinery operations often result in formation of impeding layers in the subsurface soil due to compaction (Horn and Smucker, 2005). Therefore, subsurface lateral flow may be intensified in agricultural catchment and have more implication to surface water quality when nutrients leached and accumulated in the subsurface soil (Garg et al., 2005).

Hillslopes are the fundamental units of hilly or mountainous landscapes (Bronstert and Plate, 1997; Zehe and Blöschl, 2004; Lin et al., 2006). Subsurface lateral flow from hillslopes and its connectivity to stream flow have been studied by monitoring the dynamics of soil moisture profiles along slopes (Lin, 2006; McNamara et al., 2005; Zhu and Lin, 2009) or trench flow below hillslopes (Newman et al., 1998; Tromp-van Meerveld and McDonnell, 2006; van Verseveld et al., 2009) or both of them (Burke and Kasahara, 2011).
Spatial variations of soil water content within soil profiles measured in those studies (Burke and Kasahara, 2011; Inamdar and Mitchell, 2007; Lin, 2006) gave hints of generation of subsurface lateral flow, but no hints about how it was generated as soil water movement is normally driven by the difference in soil water potential rather than by the difference in soil water content. This can be improved by monitoring soil water potential. Single trench flow measurement often gives more direct evidences of generation of subsurface flow than soil water monitoring, but the results often need careful interpretation as they may be affected by the characteristics of trenched cross-section and the saturated flow around the trenches (Tromp-van Meerveld et al., 2007) as well as by the representativeness of the trenched hillslopes and their connection to riparian zones within catchment (van Verseveld et al., 2009). Moreover, most of the trenched hillslope experiments often lack detailed hydro-biogeochemical data that are needed for flow separation and further understanding of the hydrological processes at different scale (e.g. Hornberger et al., 1994; Boyer et al., 1997). Therefore, integrative study combining hillslope soil hydrology, trench stream and catchment hydrology and biogeochemistry may improve our understanding of generation of subsurface lateral flow from hillslopes and its contribution to nutrient delivery to the streams at the catchment scale (Cras et al., 2007).

An agricultural catchment (46.2 ha) has been used for multi-scale study on hydrological processes in subtropical China (Zepp et al., 2005). This study catchment has mixed land uses on hillslopes and terraced paddy fields. The catchment has a unique feature that irrigation channels were trenched right below hillslopes. Thus, all the hillslope flows issue directly into the irrigation stream, without any riparian zone modulation. This feature made it possible to identify and quantify subsurface lateral flow from hillslopes to streams by simultaneously monitoring hillslope soil hydrology and stream hydrology during rainstorm events. It was hypothesized that the stream flows on the cropped hillslope and at the catchment outlet corresponded to soil water movement from the hillslopes and that the stream flow chemistry at the catchment outlet changed with subsurface lateral flow from the hillslopes. The objectives of this study were to examine how subsurface lateral flow generated through soil pedons from cropped hillslopes and to quantify its contribution to nitrate loading in the streams through an agricultural catchment. The dynamics of soil water movement along the hillslopes under two land uses and the dynamics of stream flow in the streams trenched below the cropped hillslope and at the catchment outlet were compared during two rainstorm events and the contribution of subsurface lateral flow to nutrient loadings in the streams was assessed by hydrograph separation using mixing chemical modeling. 


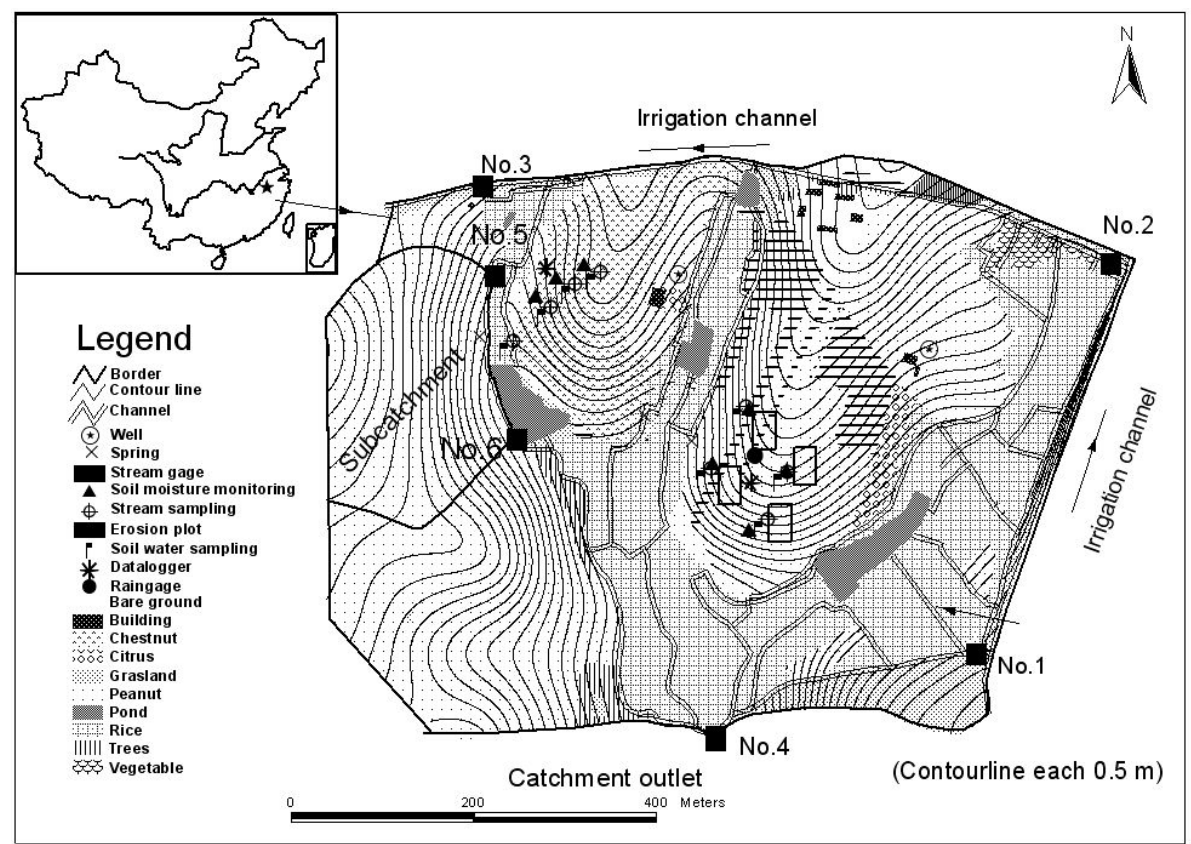

Fig. 1. Sketch of studied Sunjia catchment, showing the station positions at the irrigation inlets (Station No. 1 and Station No. 2), irrigation outlet (Station No. 3), catchment outlet (Station No. 4), and the inlet (Stations No. 5) and outlet (Station No. 6) of the subcatchment (after Tang et al., 2008).

\section{Materials and methods}

\subsection{Study site and catchment}

The research Sunjia catchment is located approximately $4 \mathrm{~km}$ away from the Ecological Experimental Station of Red Soil, Chinese Academy of Sciences $\left(28^{\circ} 15^{\prime} \mathrm{N}, 116^{\circ} 55^{\prime} \mathrm{E}\right)$, in Yingtan, Jiangxi Province. It is representative of widespread geomorphology and land uses in the low hilly region in southeast China. The catchment has an area of 46.2 ha (Fig. 1). Elevations range from $55 \mathrm{~m}$ on the hills to $44 \mathrm{~m}$ in the valleys and slopes are around $5 \%$ to $8 \%$. The catchment has been intensively used for agriculture, with mixed land uses on slope uplands and terraced paddy fields. The upland slopes were cultivated for rain-fed peanut (Arachis hypogaea L.) crop (47.9\%), agroforestry system consisting of peanut crop intercropped with mandarin orange (Citrus reticulate L.) tree $(11.7 \%)$ and chestnut (Castanea mollissima L.) orchard $(8.1 \%)$. The peanut crops having shallow roots were cultivated from early April to early August, with the leaf area index being about 3.2 from late May to late July. The mandarin orange and chestnut trees having deep roots received twice tillage a year for fertilization around each tree, with a small proportion of surface area disturbed. The paddy fields $(29.5 \%)$ were cultivated with double rice (Oriza sativa L.) cropping followed by winter fallow. The remaining lands $(2.8 \%)$ were occupied by ponds and residence.

The research area has a subtropical moist climate, with a mean annual temperature of $17.7^{\circ} \mathrm{C}$, a maximum daily temperature of around $40{ }^{\circ} \mathrm{C}$ in summer and an annual average of 262 frost-free days. Annual rainfall is $1786 \mathrm{~mm}$ and potential evaporation measured using E601 evaporation pan is $1230 \mathrm{~mm}$. About $50 \%$ of the annual rainfall falls between March and early July, during which period potential evaporation was lower than rainfall. Potential evaporation exceeds rainfall from late July to November, causing seasonal drought. Stream flow discharges in the catchment consequently exhibit strong seasonality, with high base flow during the irrigation period and ephemeral drying-up periods after irrigation stopped since October in the dry season (Tang et al., 2007, 2008). The geology in the region consists of weakly weathered Cretaceous sandstone underlying deeply weathered Quaternary red clay, resulting in the formation of lateritic profiles on the hills: surficial clayey, sandy or their mixture deposits, ferruginized caprock and mottled zone, overlying weakly weathered sandstone. Sandy soils were exposed in some locations due to long-term soil erosion of clayey soils overlying. The soil depths on the hills are generally shallow $(<3 \mathrm{~m})$ and there is no deep ground water on the hillslopes as identified with radiation method (data not reported) and in the stream hydrographs (Tang et al., 2007, 2008).

The selected soil physical and hydraulic properties are presented in Table 1 for the hillslopes under peanut cropping system and chestnut orchard. Soil water retention curves were measured using wind evaporation method (Wessolek et al., 1994; Jing et al., 2008) to estimate the saturated hydraulic conductivity $\left(K_{\mathrm{S}}\right)$ by fitting the Mualem-van 
Table 1. Soil texture, bulk density and saturated hydraulic conductivity $\left(K_{\mathrm{S}}\right)$ estimated from the soil water retention curves by soil horizon and slope position under the peanut cropping system and chestnut orchard.

\begin{tabular}{|c|c|c|c|c|c|c|c|c|}
\hline \multirow[t]{2}{*}{ Land use } & \multirow{2}{*}{$\begin{array}{l}\text { Slope } \\
\text { position }\end{array}$} & \multirow{2}{*}{$\begin{array}{l}\text { Soil } \\
\text { horizon* }\end{array}$} & \multirow{2}{*}{$\begin{array}{l}\begin{array}{l}\text { Soil } \\
\text { depth }\end{array} \\
\text { m }\end{array}$} & \multicolumn{3}{|c|}{ Soil texture** } & \multirow{2}{*}{$\begin{array}{c}\text { Bulk Density } \\
\mathrm{Mg} \mathrm{m}^{-3}\end{array}$} & \multirow{2}{*}{$\begin{array}{c}K_{\mathrm{S}} \\
\mathrm{md}^{-1}\end{array}$} \\
\hline & & & & $\begin{array}{c}\text { Clay } \\
\mathrm{g} \mathrm{kg}^{-1}\end{array}$ & $\begin{array}{c}\text { Silt } \\
\mathrm{g} \mathrm{kg}^{-1}\end{array}$ & $\begin{array}{c}\text { Sand } \\
\mathrm{g} \mathrm{kg}^{-1}\end{array}$ & & \\
\hline \multirow{8}{*}{$\begin{array}{l}\text { Peanut } \\
\text { cropping system }\end{array}$} & Upper slope & Ap & $0-0.25$ & 354 & 240 & 406 & 1.23 & 2.40 \\
\hline & & $\mathrm{AB}$ & $0.25-0.50$ & 368 & 259 & 373 & & \\
\hline & & $\mathrm{Bt}$ & $0.50-1.00$ & 423 & 232 & 345 & 1.43 & 0.64 \\
\hline & & $\mathrm{BCv}$ & $1.00-1.30$ & 450 & 150 & 400 & 1.51 & 0.30 \\
\hline & Lower slope & Ap & $0-0.25$ & 252 & 208 & 540 & 1.38 & 1.98 \\
\hline & & Bt1 & $0.25-0.50$ & 410 & 90 & 500 & & \\
\hline & & Bt2 & $0.50-0.90$ & 354 & 146 & 500 & 1.51 & 0.70 \\
\hline & & Bt3 & $0.90-1.30$ & 275 & 145 & 580 & 1.55 & 0.26 \\
\hline \multirow[t]{12}{*}{ Chestnut forest } & Upper slope & Ap & $0-0.20$ & 171 & 131 & 698 & 1.48 & 2.80 \\
\hline & & Bt1 & $0.20-0.50$ & 284 & 182 & 534 & & \\
\hline & & Bt2 & $0.50-0.70$ & 390 & 189 & 421 & 1.66 & 0.40 \\
\hline & & $\mathrm{BCv}$ & $0.70-1.45$ & 346 & 193 & 461 & 1.67 & 0.11 \\
\hline & Middle slope & Ap & $0-0.20$ & 200 & 122 & 678 & 1.59 & 3.60 \\
\hline & & Bt1 & $0.20-0.50$ & 374 & 123 & 503 & & \\
\hline & & Bt2 & $0.50-0.80$ & 296 & 186 & 518 & 1.64 & 0.40 \\
\hline & & $\mathrm{BCv}$ & $0.80-1.40$ & 312 & 148 & 540 & 1.60 & 0.11 \\
\hline & Lower slope & Ap & $0-0.20$ & 169 & 200 & 631 & 1.58 & 3.02 \\
\hline & & Bt1 & $0.20-0.90$ & 235 & 251 & 514 & & \\
\hline & & Bt2 & $0.90-1.30$ & 298 & 199 & 503 & 1.46 & 0.40 \\
\hline & & $\mathrm{BCv}$ & $1.30-1.80$ & 292 & 185 & 523 & 1.50 & 0.08 \\
\hline
\end{tabular}

* The small letters for soil horizons are: $p$, plough layer, $t$, accumulation of silicate clay; and $v$, plinthic.

** Clay, $<0.002 \mathrm{~mm}$, Silt, 0.002-0.05 mm; Sand, >0.05 mm.

Genuchten unsaturated conductivity model (Mualem, 1976; van Genuchten, 1980). Detailed information on the methods can be found from Jing et al. (2008). The soil hydraulic properties along the hillslopes were reported anisotropic in the surface soil $(0-0.10 \mathrm{~m})$, with a greater hydraulic conductivity in the vertical direction than the along contour and along slope directions, and isotropic in the deep soil layer (1.0 to $1.5 \mathrm{~m}$ ) among the three directions (Jing et al., 2008).

\subsection{Hydrological monitoring at multiple scales}

The catchment was equipped in 2001 to monitor rainfall, irrigation water, well water, spring water, soil water, overland flow, stream flow and through-fall (Zepp et al., 2005; Tang et al., 2007, 2008). With consideration of the multi-scale interactions of hydrological processes in relation to soil and nutrient transport, gauging and sampling stations were installed at different scales from the erosion plots, through the hillslopes, to the catchment outlet (Fig. 1). Briefly, sets of tensiometers and suction cups were installed at the same elevation on the upper and lower slope positions on the peanut hillslope and at the upper, middle and lower slope positions on the chestnut hillslope. The tensiometers equipped with pressure transducers (26PCDFA6G, Honeywell, USA) were installed at the depths of $0.20,0.40,0.60,0.85$, and $1.50 \mathrm{~m}$ to measure soil matric potential $(\Psi)$. The pressure transducers, covering a range of $\pm 30.0 \mathrm{psi}$ or $\pm 206.84 \mathrm{kPa}$ and having a very fast response time $(<1 \mathrm{~ms})$, were connected to a data-logger (DL2, Delta T, Lt., UK) to record the readings at 10-min intervals. Soil water potential was soil matric potential plus gravity potential at the depth where a tensiometer was installed. Suction cups were installed at the depths of $0.20,0.40$ and $0.85 \mathrm{~m}$ for soil water sampling. A suction of $100 \mathrm{kPa}$ was applied for one week before each sampling day. Erosion plots, $5 \mathrm{~m}$ wide and $20 \mathrm{~m}$ long along the hillslopes, were positioned at the upper and lower slope positions along the peanut slope, with the tensiometers lining in the middle of the erosion plots. Overland flow and sediments were conducted to a tipping bucket system following the design reported by Khan and Ong (1997) to automatically sample water, sediment and record tipping number using event data loggers (Onset Computer Corporation, USA) and then calculate overland flow and sediment load on event base. 
The study catchment had irrigation channels trenched below the hill slopes and in the valley among the paddy fields (Fig. 1). The channels below the slopes were also used to drain overland flow from the slopes during rainfall and base flow if any after rainfall. Hydrological weirs were constructed at the catchment inlets (Stations No. 1, 2 and 3) and the catchment outlet (Station No. 4) and in a trenched stream right below a peanut cropping hillslope within the catchment (Stations No. 5 and 6). The hydrological area of the peanut hillslope was delineated by geographical information system (GIS) software (Fig. 1) and it was about one tenth of total catchment area (4.8 ha). Water levels at the hydrological stations were measured at 10-min intervals using water level transducers connected to data-loggers (Keller Company, Switzerland) and were converted into stream flow flux. Water sampling was carried out weekly and simultaneously from all water sources, including soil water and stream water from the above-mentioned sites, the well locating in the chestnut orchard, and the spring lying between Stations No. 5 and No. 6. The well water and spring water represented the subsurface soil water. Although the sites for soil water sampling were not located within the peanut hillslope, we assumed that soil water chemistry was similar under the same soil condition and cropping system.

In addition to the regular weekly sampling, stream water was sampled at relative short intervals from 20 to $60 \mathrm{~min}$ during storm events. There were total 23 sampled rainfall events (8 in 2002, 6 in 2003, and 9 in 2004) and most of the events data were not completed due to the limitation of manual sampling in the dark conditions during night when rainfall peaks appeared. Two heavy storm events are presented here because the datasets were available to compare the profiles of soil water potential on the hillslopes and the hydrographs of the streams below the peanut hillslope and at the catchment outlet. More importantly, the stream flow chemistry data sets covered the whole period during the period of rainstorms and several hours after the end of the rainstorms. The rainstorm on 14 May 2003 lasted for $1020 \mathrm{~min}$, with the total amount of $178.5 \mathrm{~mm}$ and the maximum rainfall intensity within $30 \mathrm{~min}$ of $27 \mathrm{~mm} \mathrm{~h}^{-1}$. Another rainstorm on 12 May 2004 lasted for 1320 min, with the total amount of $124.5 \mathrm{~mm}$ and the maximum rainfall intensity within $30 \mathrm{~min}$ of $14 \mathrm{~mm} \mathrm{~h}^{-1}$. There were $68.5 \mathrm{~mm}$ and $53.5 \mathrm{~mm}$ rainfalls within 5 days before the rain storms on 14 May 2003 and on 12 May 2004, respectively.

The water samples were stored at about $4{ }^{\circ} \mathrm{C}$ in laboratory of the experimental station before chemical analysis of total nitrogen (TN), total phosphorus (TP), nitrate-nitrogen $\left(\mathrm{NO}_{3}^{-}\right.$$\mathrm{N})$ and ammonium-nitrogen $\left(\mathrm{NH}_{4}^{+}-\mathrm{N}\right)$. TN and $\mathrm{TP}$ concentrations were measured before and after filtering through the filter paper of $0.45 \mu \mathrm{m}$ pore size. TN and TP measured after the filtering were taken as total dissolved nitrogen (TDN) and total dissolved phosphorus (TDP), respectively. The difference between TN and TDN was referred to as
particulate-N (PN) and between TP and TDP was referred to as particulate-P (PP). The water samples were digested with $\mathrm{K}_{2} \mathrm{~S}_{2} \mathrm{O}_{8}-\mathrm{NaOH}$ solution before TN and TDN measurement and with $\mathrm{K}_{2} \mathrm{~S}_{2} \mathrm{O}_{4}$ before TP and TDP measurement. TN and $\mathrm{NO}_{3}^{-}-\mathrm{N}$ were determined by ultraviolet spectrophotometry. $\mathrm{NH}_{4}^{+}-\mathrm{N}$ and TP were determined by colorimetry. Suspended sediment concentrations were measured by weighing after being filtered and dried. Electricity conductivity (EC) and $\mathrm{pH}$ in water samples were also measured using meters constructed by the Institute of Soil Science, Chinese Academy of Sciences (ISSCAS).

The sediment and chemical datasets were summarized for the period from 2001 to 2004, The statistics were given for soil water at the $0.85 \mathrm{~m}$ depth under peanut cropping system $(n=55)$, well water, spring water and irrigation water at Station No. $2(n=150)$ based on the regular sampling and for rainfall water $(n=153)$, overland flow $(n=169)$ under the different land uses and stream flow at the catchment outlet $(n=121)$ and within the subcatchment $(n=121)$ based on the intensive monitoring during storms. An analysis of variance (ANOVA) was performed to compare the nutrient concentrations from different water sources using SPSS 11.5. The least significant difference (LSD) test was adopted to assess the significant differences at $\mathrm{P}<0.05$ or $\mathrm{P}<0.01$ among the water sources. The statistics was used to compare with the previous study for the period from 2001 to 2003 (Tang et al., 2008) to determine if the chemical properties such as $\mathrm{pH}$ and $\mathrm{EC}$ were distinct among the water sources all the time.

\subsection{Separation of subsurface lateral flow from stream flow}

The components of stream water were estimated by hydrograph separation using chemical mixing model (Raiswell, 1984; Hagedorn, 1999). Given that their distinction among the water sources from overland flow, irrigation water to soil water (Tang et al., 2008; Table 2) and their conservativity during the relative short periods of rainstorms, $\mathrm{pH}$ and $\mathrm{EC}$ were used to separate soil water component in stream flow by solving the following mass-balance equations:

$$
\begin{aligned}
& Q_{c}=Q_{o}+Q_{i}+Q_{s} \\
& Q_{c} C_{1 c}=Q_{o} C_{1 o}+Q_{i} C_{1 i}+Q_{s} C_{1 s} \\
& Q_{c} C_{2 c}=Q_{o} C_{2 o}+Q_{i} C_{2 i}+Q_{s} C_{2 s}
\end{aligned}
$$

where $Q$ is the stream flow and the subscripts $c, o, i, s$ refer to stream flow, overland flow from the erosion plots, irrigation water and soil water, respectively; $C_{1}$ and $C_{2}$ are $\mathrm{H}^{+}$ concentration and $\mathrm{EC}$ value measured during the two storm events on 14 May 2003 and 12 Ma 2004.

The uncertainty of the modeling was estimated based on Gaussian error propagation and calculated using the following formula (Genereux, 1998; Lo, 2005),

$$
W_{f i}=\sqrt{\left(\frac{\partial f i}{\partial x 1}\left(W_{x 1}\right)^{2}+\left(\frac{\partial f i}{\partial x 2} W_{x 2}\right)^{2}+\ldots+\left(\frac{\partial f i}{\partial x n} W_{x n}\right)^{2}\right)}
$$


Table 2. Averages (standard deviation in the parentheses) of $\mathrm{pH}$, electricity conductivity (EC), and the concentrations of $\mathrm{NH}_{4}^{+}-\mathrm{N}, \mathrm{NO}_{3}^{-}-\mathrm{N}$, total N (TN), total P (TP) and suspended sediment concentration (SS) in different water sources following weekly sampling and intensive sampling during rainstorm from 2001 to 2004.

\begin{tabular}{|c|c|c|c|c|c|c|c|c|}
\hline Water sources & $\begin{array}{l}\text { Sampling } \\
\text { strategies }\end{array}$ & $\mathrm{pH}$ & $\begin{array}{l}\mathrm{EC} \\
\mu \mathrm{S} \mathrm{m}^{-1}\end{array}$ & $\begin{array}{l}\mathrm{NH}_{4}^{+}-\mathrm{N} \\
\mathrm{mgl}^{-1}\end{array}$ & $\begin{array}{l}\mathrm{NO}_{3}^{-}-\mathrm{N} \\
\mathrm{mgl}^{-1}\end{array}$ & $\begin{array}{l}\mathrm{TN} \\
\mathrm{mg} \mathrm{l}\end{array}$ & $\begin{array}{l}\mathrm{TP} \\
\mathrm{mg} 1^{-1}\end{array}$ & $\begin{array}{l}\mathrm{SS} \\
\mathrm{g} 1^{-1}\end{array}$ \\
\hline $\begin{array}{l}\text { Soil water at } 0.85 \mathrm{~m} \\
\text { depth on the peanut }\end{array}$ & \multirow[t]{8}{*}{$\begin{array}{l}\text { Weekly } \\
\text { sampling }\end{array}$} & $5.55 \mathrm{c}^{*}$ & $1.20 \mathrm{a}$ & $0.06 \mathrm{~b}$ & $9.26 \mathrm{a}$ & $9.52 \mathrm{a}$ & 0.01 & - \\
\hline hillslope $(n=55)$ & & $(0.49)$ & $(0.43)$ & $(0.08)$ & (6.30) & $(6.38)$ & $(0.01)$ & - \\
\hline \multirow{2}{*}{$\begin{array}{l}\text { Well water on the } \\
\text { chestnut orchard } \\
(n=150)\end{array}$} & & $4.86 \mathrm{e}$ & $1.06 \mathrm{~b}$ & $0.09 b$ & $8.96 \mathrm{~b}$ & $9.57 \mathrm{a}$ & $0.01 \mathrm{~b}$ & - \\
\hline & & $(0.51)$ & $(0.30)$ & $(0.13)$ & (2.04) & $(2.05)$ & $(0.01)$ & - \\
\hline \multirow{2}{*}{$\begin{array}{l}\text { Spring water between } \\
\text { Stations No. } 5 \text { and } \\
\text { No. } 6(n=150)\end{array}$} & & $5.53 \mathrm{c}$ & $0.26 \mathrm{e}$ & $0.06 \mathrm{~b}$ & $1.39 \mathrm{c}$ & $1.47 \mathrm{~cd}$ & $0.01 \mathrm{~b}$ & - \\
\hline & & $(0.45)$ & $(0.22)$ & $(0.09)$ & (1.58) & $(1.17)$ & $(0.01)$ & - \\
\hline \multirow{2}{*}{$\begin{array}{l}\text { Irrigation water at } \\
\text { the catchment inlet } \\
(n=150)\end{array}$} & & $6.95 \mathrm{a}$ & $0.48 \mathrm{c}$ & $0.06 \mathrm{~b}$ & $0.24 \mathrm{e}$ & $0.51 \mathrm{e}$ & $0.03 b$ & - \\
\hline & & $(0.70)$ & $(0.15)$ & $(0.08)$ & (0.18) & $(0.27)$ & $(0.06)$ & - \\
\hline \multirow{2}{*}{$\begin{array}{l}\text { Overland flow from } \\
\text { erosion plots on the } \\
\text { peanut hillslope } \\
(n=169)\end{array}$} & \multirow[t]{7}{*}{$\begin{array}{l}\text { Intensive } \\
\text { sampling }\end{array}$} & $5.50 \mathrm{c}$ & $0.15 f$ & $0.10 \mathrm{~b}$ & $0.35 \mathrm{de}$ & $2.74 \mathrm{~b}$ & $0.50 \mathrm{a}$ & $4.45 \mathrm{a}$ \\
\hline & & $(0.44)$ & $(0.11)$ & $(0.56)$ & $(0.94)$ & $(1.76)$ & $(0.32)$ & $(8.93)$ \\
\hline $\begin{array}{l}\text { Rainfall water } \\
(n=153)\end{array}$ & & $\begin{array}{l}5.26 \mathrm{~d} \\
(0.72)\end{array}$ & $\begin{array}{l}0.26 \mathrm{e} \\
(0.20)\end{array}$ & $\begin{array}{l}0.57 \mathrm{a} \\
(0.55)\end{array}$ & $\begin{array}{l}0.47 \mathrm{de} \\
(0.43)\end{array}$ & $\begin{array}{l}1.17 \mathrm{~d} \\
(1.09)\end{array}$ & $\begin{array}{l}0.02 \mathrm{~b} \\
(0.04)\end{array}$ & $\begin{array}{l}- \\
-\end{array}$ \\
\hline $\begin{array}{l}\text { Stream water at } \\
\text { Station No. } 4 \\
\text { (catchment outlet) }\end{array}$ & & $6.22 \mathrm{~b}$ & $0.38 \mathrm{~d}$ & $0.17 \mathrm{~b}$ & $0.76 \mathrm{~cd}$ & $1.90 \mathrm{c}$ & $0.02 b$ & $2.66 \mathrm{~b}$ \\
\hline$(n=121)$ & & $(0.39)$ & $(0.10)$ & $(0.28)$ & $(0.43)$ & $(1.00)$ & $(0.03)$ & $(8.33)$ \\
\hline $\begin{array}{l}\text { Stream water at } \\
\text { Station No. } 5(n=121)\end{array}$ & & $\begin{array}{l}5.94 \mathrm{~b} \\
(0.42)\end{array}$ & $\begin{array}{l}0.42 \mathrm{~cd} \\
(0.17)\end{array}$ & $\begin{array}{l}0.19 b \\
(0.51)\end{array}$ & $\begin{array}{l}1.46 \mathrm{c} \\
(0.95)\end{array}$ & $\begin{array}{l}2.98 \mathrm{~b} \\
(1.50)\end{array}$ & $\begin{array}{l}0.19 \mathrm{~b} \\
(0.33)\end{array}$ & $\begin{array}{l}2.93 \mathrm{~b} \\
(7.78)\end{array}$ \\
\hline $\begin{array}{l}\text { Stream water at } \\
\text { Station No. } 6(n=121)\end{array}$ & & $\begin{array}{l}5.87 \mathrm{~b} \\
(0.47)\end{array}$ & $\begin{array}{l}0.41 \mathrm{~cd} \\
(0.14)\end{array}$ & $\begin{array}{l}0.20 \mathrm{~b} \\
(0.38)\end{array}$ & $\begin{array}{l}1.22 \mathrm{c} \\
(0.89)\end{array}$ & $\begin{array}{l}2.88 \mathrm{~b} \\
(1.49)\end{array}$ & $\begin{array}{l}0.25 b \\
(0.34)\end{array}$ & $\begin{array}{l}3.23 \mathrm{~b} \\
(5.90)\end{array}$ \\
\hline
\end{tabular}

- not detectable; * the different letters in columns indicate significant differences at $\mathrm{P}<0.05$ among the water sources.

where $W_{f i}$ is the uncertainty value for $i$-th flow component; $W_{x i}$ is the analytical uncertainties of chemical constituents in different water sources; $f$ is the proportion of water source in total stream flow.

The $\mathrm{NO}_{3}^{-}-\mathrm{N}$ concentration in stream flow was predicted by summing every separated flow component multiplied with the measured concentration in each component's source, following Eqs. (2) or (3). The predicted $\mathrm{NO}_{3}^{-}-\mathrm{N}$ concentration was then compared with observed the $\mathrm{NO}_{3}^{-}-\mathrm{N}$ concentration to evaluate the applicability of chemical mixing model using the coefficient of determination $\left(R^{2}\right)$ and the Nash-Sutcliffe model efficiency $(E)$ (Nash and Sutcliffe, 1970).

\subsection{Estimation of nitrogen loading with subsurface lateral flow}

Loadings of $\mathrm{TN}$ and $\mathrm{NO}_{3}^{-}-\mathrm{N}$ in the streams from the peanut hillslope and the whole catchment were calculated following Eq. (5).
$L=\sum_{1}^{n} C_{i} \times Q_{i} \times \Delta t_{i}$

where $L$ is the $\mathrm{TN}$ or $\mathrm{NO}_{3}^{-}-\mathrm{N}$ loads during a sampling period; $\Delta t_{i}$ is the time interval between each sampling; $C_{i}$ is the TN concentration measured in the stream flow at the $i$ th sampling time or the $\mathrm{NO}_{3}^{-}-\mathrm{N}$ concentration measured in the soil water source before the event; $Q_{i}$ is the amount of the measured stream flow or the estimated subsurface lateral flow at the $i$-th sampling time.

\section{Results}

\subsection{Chemistry of different water sources}

The differences in water chemistry were distinct $(\mathrm{P}<0.05)$ among the water resources within the agricultural catchment during the period from 2001 to 2004 (Table 2), confirming 

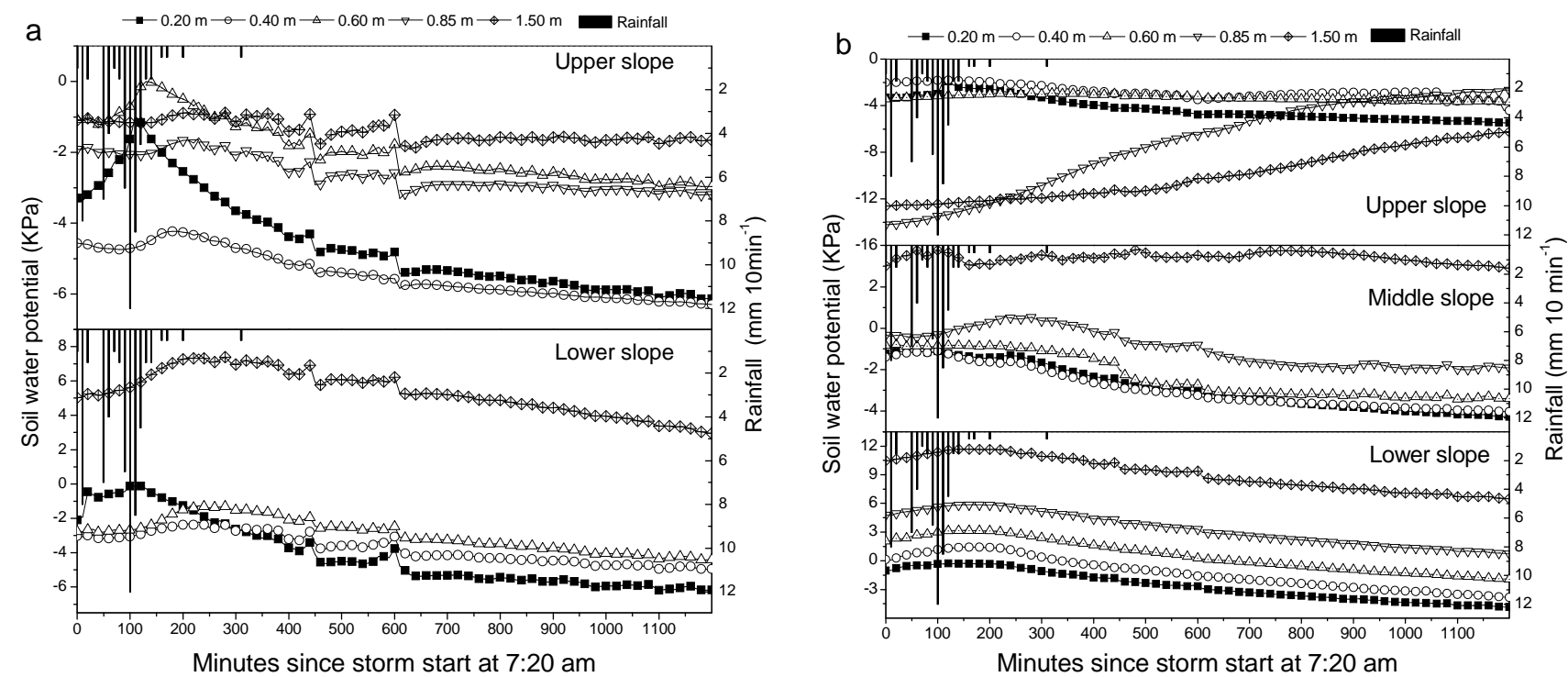

Fig. 2. Profiles of soil water potential over time for the 14 May 2003 storm on different positions of the peanut cropping hillslope (a) and the chestnut orchard hillslope (b). Missing depth was due to malfunction of the tensiometers.

the same trend as reported in our previous study from 2001 to 2003 (Tang et al., 2008). By the regular sampling, the irrigation water had greater $\mathrm{pH}$ than all the subsurface water (the spring water, soil water at $0.85 \mathrm{~m}$ depth, and the well water) and lower EC than in the soil water and the well water. By the intensive sampling, the overland flow had higher $\mathrm{pH}$, but lower EC than the rainfall water, and all the stream waters increased $\mathrm{pH}$ and $\mathrm{EC}$, probably because the acid Ultisol is poor in base ions in surface layer (Xu et al., 2003). There were no significant differences in $\mathrm{pH}$ and $\mathrm{EC}$ among the stream waters during the rainfall. In both sampling strategies, $\mathrm{NH}_{4}^{+}$$\mathrm{N}$ concentration was lower than $0.20 \mathrm{mgl}^{-1}$ in all the water sources except for the rainfall water $\left(0.57 \pm 0.55 \mathrm{mg}^{-1}\right)$. Such high $\mathrm{NH}_{4}^{+}$-N concentration was reported in the same region by Hu et al. (2007) and could be attributed to direct ammonium volatilization from intensive fertilization to paddy fields and from pig raising yard. In contrast, $\mathrm{NO}_{3}^{-}-\mathrm{N}$ concentration was the greatest in the soil water and the well water, followed by the surface stream waters, and the lowest in other water sources. There were no significant differences in $\mathrm{NO}_{3}^{-}-\mathrm{N}$ concentration among the stream waters and among the rainfall, overland flow and irrigation waters. $\mathrm{NO}_{3}^{-}-\mathrm{N}$ concentration was higher in the stream waters than in the rainfall, irrigation and overland flow waters. Suspended sediment and TP were detected only during the storms, with higher concentrations in the overland flow than the stream flow waters $(\mathrm{P}<0.05)$. Particulate $\mathrm{P}$ accounted for nearly $100 \%$ of TP.

\subsection{Hillslope soil hydrology during storm events}

The soil water potential responded rapidly to the rainfall intensity during the storm and the responses varied with hillslope position and land use for the two storm events (Figs. 2 and 3). The soil water potential was always negative at the 0.20 and $0.40 \mathrm{~m}$ depths under both land uses and storm events. The soil water potential on 14 May 2003 became positive during the rainfall, meaning saturated, at the $0.60 \mathrm{~m}$ and $1.5 \mathrm{~m}$ depths on the upper and lower hillslope positions under the peanut cropping system (Fig. 2a), and then decreased after the end of rainfall. The decrease was quicker at the 0.20 and $0.40 \mathrm{~m}$ depths than at other layers and on the upper slope than on the lower slope, indicating a fast drainage along the hillslope. On the chestnut hillslope (Fig. 2b), the positive soil water potential appeared during the course of rainfall at the 0.85 and $1.50 \mathrm{~m}$ depths at the middle and lower hillslope positions and then decreased after the end of rainfall. The soil water potential at the $1.50 \mathrm{~m}$ depth on the lower slope position continued to increase for 110 or $120 \mathrm{~min}$ after the maximum rainfall intensity and reach a peak at $7.6 \mathrm{kPa}$ under the peanut cropping system, and a peak at $11.6 \mathrm{kPa}$ under the chestnut orchard. The peaks of positive soil water potential illustrated that the depth of perched soil water table over the $1.50 \mathrm{~m}$ soil depth was $0.76 \mathrm{~m}$ and $1.17 \mathrm{~m}$ at the lower hillslope positions on the peanut hillslope and the chestnut hillslope, respectively.

The dynamics of soil water potential on 12 May 2004 (Fig. 3) also demonstrated the processes of soil water saturation and drainage along the slope. The soil water potential at the $1.50 \mathrm{~m}$ depth on the lower hillslope position continued to increase for 400 and $250 \mathrm{~min}$ after the maximum rainfall intensity and reached the peaks on the peanut hillslope and chestnut hillslope, respectively. The peaks of soil water potential showed that the depth of perched soil water table over the $1.50 \mathrm{~m}$ soil depth was $0.54 \mathrm{~m}$ at the lower slope position 

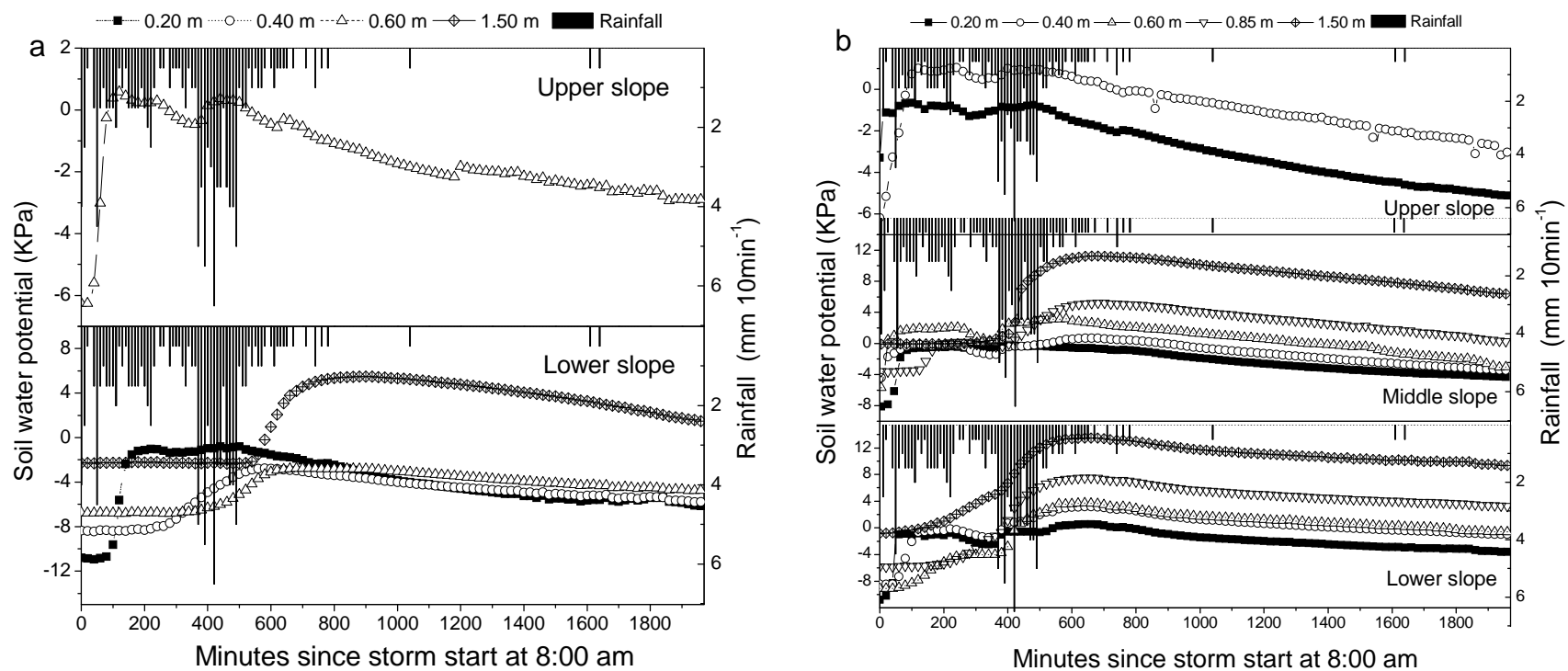

Fig. 3. Profiles of soil water potential over time for the 12 May 2004 storm event on different positions of the peanut cropping hillslope (a) and the chestnut orchard hillslope (b). Missing depths were due to malfunction of the tensiometers.

on the peanut hillslope (Fig. 3a) and $1.13 \mathrm{~m}$ and $1.35 \mathrm{~m}$ on the middle and lower hillslope positions on the chestnut hillslope (Fig. 3b).

\subsection{Stream hydro-chemo-graphs during storm events}

The hydrographs and chemographs during the two storm events are illustrated in Figs. 4 and 5. The peak flows at Station No. 4, No. 5 and No. 6 were 7751,70 and $2151 \mathrm{~s}^{-1}$ and on 14 May 2003 (Fig. 4), and 3936, 161 and $2111 \mathrm{~s}^{-1}$ on 12 May 2004 (Fig. 5). The hydrographs at each gauging station showed different patterns on the rising limbs during the rainfall, but similar patterns on the recession limbs after the end of rainfall. The flow recession was delayed as compared with the normal recession and even increased at all stations after both storms had stopped except for at Stations No. 6 and No. 4 on 12 May 2004 (Fig. 4). The delayed flow recession indicated a flush from new water source. The new water source could be only a subsurface lateral flow as there was no overland flow and irrigation flow was stable before and after the end of rainfall (data from Station No. 3 were not shown here).

The stream chemical parameters can be categorized into three groups, particulate nutrients (PN and $\mathrm{PP}$ ) and suspended sediment (SS), soluble nutrients $\left(\mathrm{NO}_{3}^{-}-\mathrm{N}\right.$ and $\left.\mathrm{K}\right)$, and $\mathrm{EC}$ and $\mathrm{pH}$. The chemographs in each chemical category showed similar patterns at all the gauging stations during the two storm events. The concentrations of $\mathrm{N}$ and $\mathrm{P}$ in all forms were higher in the trenched stream below the peanut hillslope (Stations No. 5 and No. 6) than at the catchment outlet (Station No. 4) in each of the storms. The concentrations of PN and PP and SS increased with time during the rainfall on the rising limb of each hydrograph and reached their peaks prior to the peak stream flow and diminished immediately after the end of the rainfall. The peak PN and PP concentrations appeared at the greatest rainfall intensity or at the time when the stream flow started to increase at a greater rate and appeared earlier at Stations No. 5 and 6 than at Station No. 4. The time of peak PP and PN concentrations was about 40 minutes prior to peak flow at Stations No. 5 and 6 and about $40 \mathrm{~min}$ behind the peak flow at Station No. 4. On 12 May 2004, the time was about $80 \mathrm{~min}$ and 100 min prior to the peak stream flows at Stations No. 5 and 6 and at Station No. 4, respectively. The particulate NN and $\mathrm{P}$ accounted for $>90 \%$ of TN and about $100 \%$ of TP, and their concentrations were significantly correlated with SS concentration and stream flow. Particulate N concentration was significantly correlated with both SS concentration and stream flow $(\mathrm{R}>0.56, \mathrm{P}<0.01, \mathrm{~N}=25$ on 14 May 2003 and $\mathrm{R}>0.43, \mathrm{P}<0.01, \mathrm{~N}=78$ on 12 May 2004). Similarly, PP concentration was significantly correlated with both SS concentration and stream flow $(\mathrm{R}>0.29, \mathrm{P}<0.05$ for, $\mathrm{N}=25$ on 14 May 2003 and $\mathrm{R}>0.35, \mathrm{P}<0.01$ for, $\mathrm{N}=78$ on 12 May 2004).

No soluble $\mathrm{P}$ was detected in the streams. The $\mathrm{NO}_{3}^{-}$$\mathrm{N}$ concentration was relatively low during the rainfall, accounting for less than $10 \%$ and $30 \%$ of TN, respectively on 14 May 2003 and on 12 May 2004. After the end of rainfall, the $\mathrm{NO}_{3}^{-}-\mathrm{N}$ concentration increased as flow decreased, accounting for $60 \%$ to $90 \%$ of $\mathrm{TN}$ at the end of the observations. The proportion of $\mathrm{NO}_{3}^{-}-\mathrm{N}$ in $\mathrm{TN}$ after the end of rainfall was greater in the trenched stream than in at the catchment outlet. The starting time of the increase in $\mathrm{NO}_{3}^{-}-\mathrm{N}$ concentration after the rainfall met well the decrease in soil water potential from its peak at the $1.5 \mathrm{~m}$ soil depth on the lower positions of both the hillslopes. $\mathrm{EC}$ and $\mathrm{pH}$ did not respond 


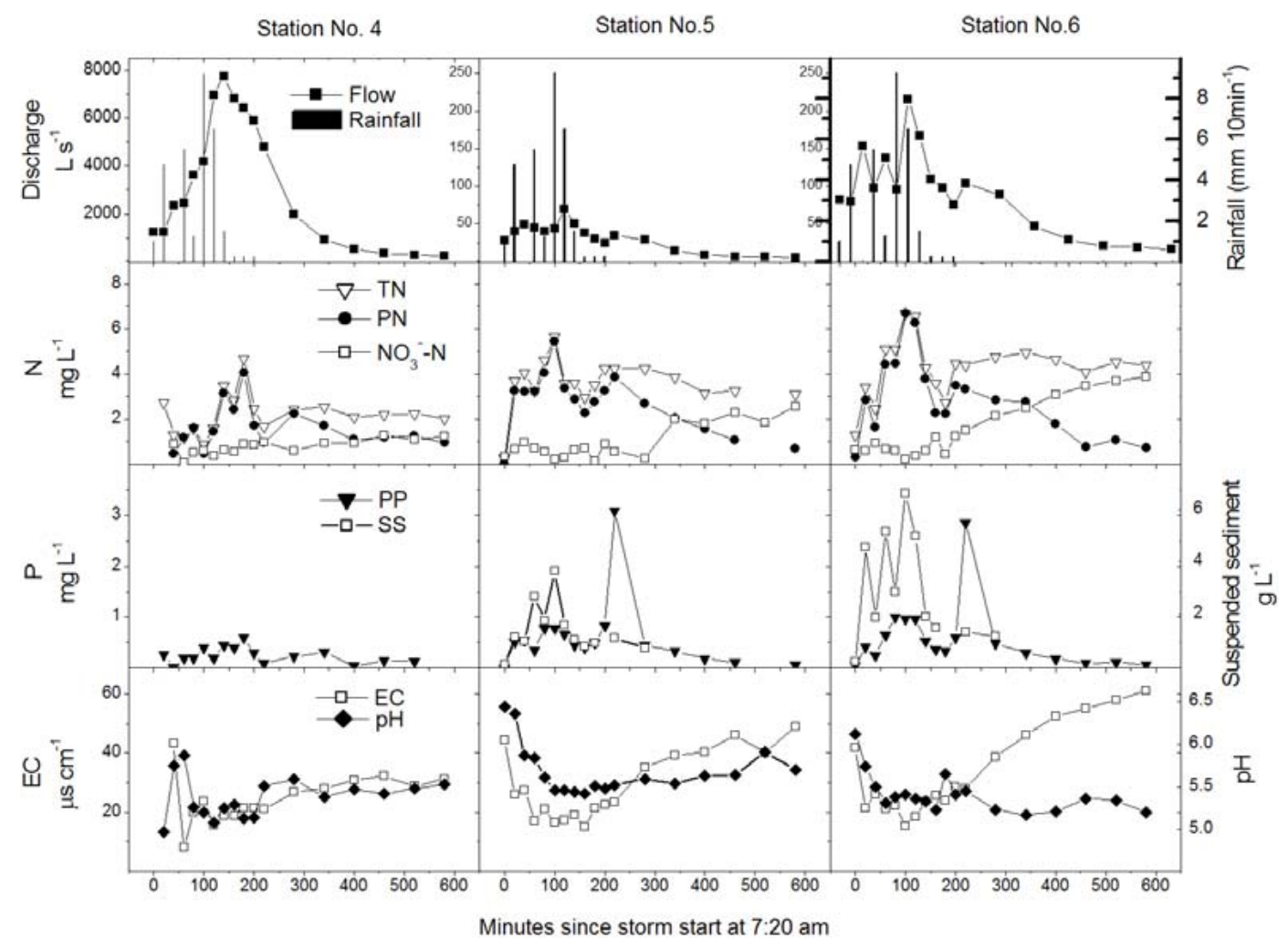

Fig. 4. Rainfall, stream discharge, total $\mathrm{N}(\mathrm{TN}), \mathrm{NO}_{3}^{-}-\mathrm{N}$, suspended sediment (SS), particulate $\mathrm{N}$ and $\mathrm{P}$ (PN and PP), electricity conductivity (EC) and $\mathrm{pH}$ in the stream water at the catchment outlet (Station No. 4) and at the inlet (Stations No. 5) and outlet (Station No. 6) of the subcatchment for the 14 May 2003 storm event.

to rainfall intensity though they generally decreased during the rainfall, while after the end of rainfall, EC increased with time and the magnitude of increase was larger in the stream below the peanut hillslope than at the catchment outlet. After the rainfall, EC was very significantly correlated to $\mathrm{NO}_{3}^{-}-\mathrm{N}$ concentration ( $\mathrm{P}<0.01$ for both the rainfall events).

\subsection{Stream flow separation and $\mathrm{NO}_{3}^{-}-\mathrm{N}$ export estimate}

The water chemistry among the three water sources was distinct in $\mathrm{H}^{+}$and EC (Table 2) and the mixing diagrams of $\mathrm{H}^{+}$ concentration and EC are illustrated in Figs. 6 and 7. The diagrams showed the stream chemistry at all the stations were similar to irrigation water at the beginning of the observation, and became more similar to the overland flow chemistry during the rainfall and then more similar to the soil water chemistry. The water chemistry was mostly similar to soil water in the lower stream (Station No. 6), followed by the upper stream (Station No. 6), and was least similar at the catchment outlet (Station No. 4).

By solving the chemical mixing model, the different components of the stream flow were separated for the two rainstorms and their temporal dynamics at all the gauging stations are shown in Fig. 7. The initial proportion of overland flow at the beginning of the observation was relatively low during the heavy storm on 14 May 2003 and was relatively high during the long lasting storm on 12 May 2004. The initial proportion of subsurface flow was relatively low during the storms and increased after the end of rainfall. The sums of the subsurface lateral flow contributing to the stream flow below the peanut slope and at the catchment outlet are shown in Table 3. The subsurface lateral flow component derived from soil water contributed to about $10 \%$ of stream flow before and after the end of rainfall and to about $50 \%$ of stream flow after the end of rainfall. The proportion was larger in the trenched stream (Station No. 6) than at the catchment outlet (Station No. 4). The total subsurface lateral flow accounted for $5.7 \%$ to $7.3 \%$ of total flow at Station No. 4 and for $29.0 \%$ to $44.8 \%$ at Station No. 6. The uncertainty of the estimation varied from $6.4 \%$ to $46.7 \%$ and was smaller at Station No. 4 than at Station No. 6 (Table 3).

The $\mathrm{NO}_{3}^{-}-\mathrm{N}$ concentrations estimated by the mixing formula based on the separated flow components are compared with the observed $\mathrm{NO}_{3}^{-}-\mathrm{N}$ concentration for both Stations No. 6 and No. 4 for the two storm events (Fig. 8). The agreement was better at Station No. $6\left(R^{2}=0.76\right.$ and 0.98 ; $E=0.54$ and 0.88) than at Station No. $4\left(R^{2}=0.17\right.$ and 0.60, $E=-0.34$ and -1.05$)$. The estimated $\mathrm{NO}_{3}^{-}-\mathrm{N}$ export 


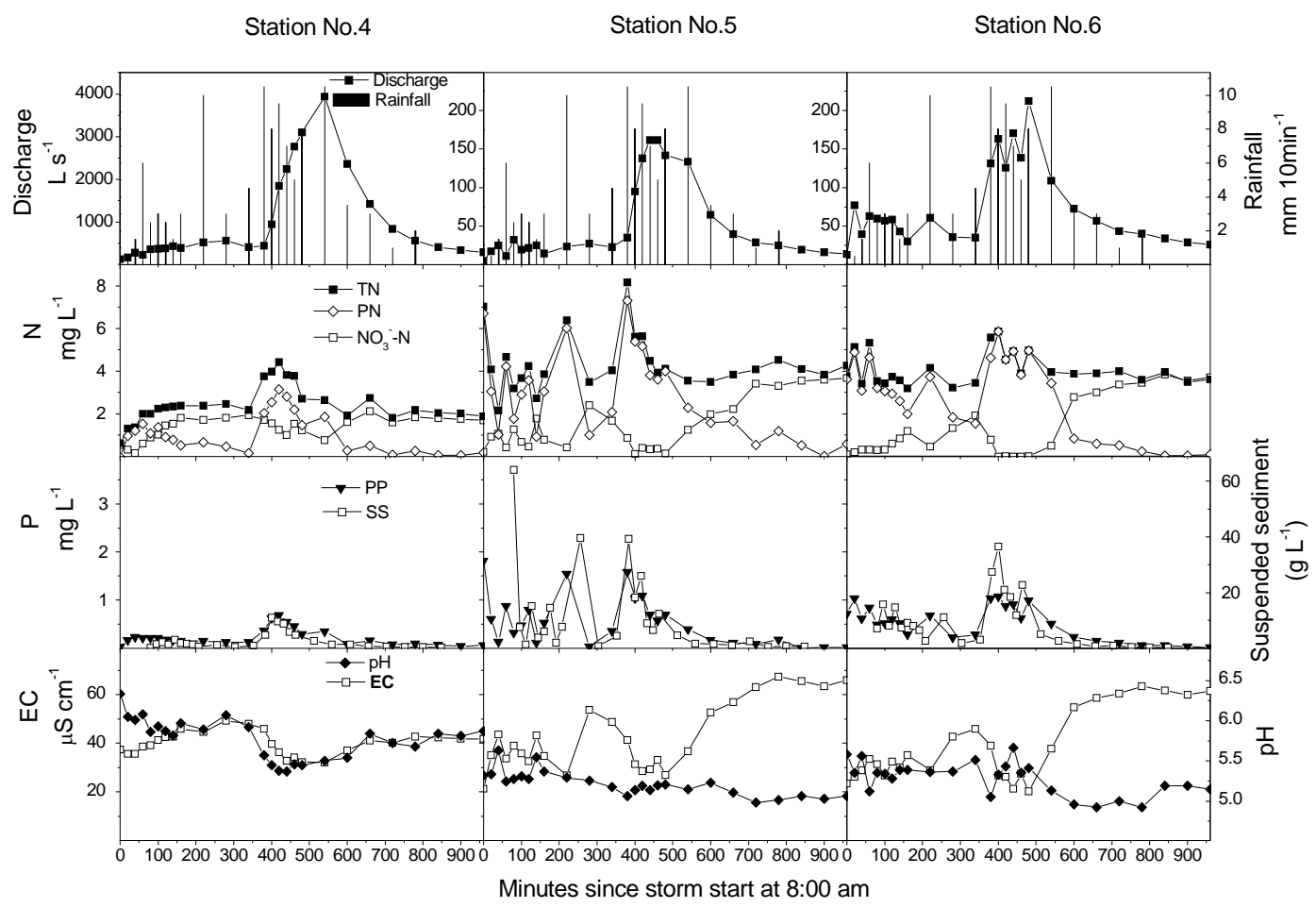

Fig. 5. Rainfall, stream discharge, total $\mathrm{N}(\mathrm{TN}), \mathrm{NO}_{3}^{-}-\mathrm{N}$, suspended sediment (SS), particulate $\mathrm{N}$ and $\mathrm{P}$ (PN and PP), electricity conductivity (EC) and $\mathrm{pH}$ in the stream water at the catchment outlet (Station No. 4) and at the inlet (Stations No. 5) and outlet (Station No. 6) of the subcatchment for the 12 May 2004 storm event.

Table 3. Total outflow and percentage of subsurface lateral flow in total outflow estimated by mixing model, total $\mathrm{N}^{(\mathrm{TN})}$ and total $\mathrm{NO}_{3}^{-}-\mathrm{N}^{-}$ (TNN) export with overland flow $\left(\mathrm{NN}_{\mathrm{O}}\right)$, irrigation flow $\left(\mathrm{NN}_{\mathrm{I}}\right)$ and subsurface lateral flow $\left(\mathrm{NN}_{\mathrm{S}}\right)$ estimated by mixing model during two storm events.

\begin{tabular}{|c|c|c|c|c|c|c|c|}
\hline \multirow[t]{2}{*}{ Station } & \multirow{2}{*}{$\begin{array}{r}\text { Total } \\
\text { outflow } \\
\left(\mathrm{m}^{3}\right)\end{array}$} & \multirow{2}{*}{$\begin{array}{l}\% \text { of subsurface } \\
\text { lateral flow } \\
\text { in total outflow* }\end{array}$} & \multirow{2}{*}{$\begin{array}{c}\mathrm{TN} \\
\left(\mathrm{kg} \mathrm{ha}^{-1}\right)\end{array}$} & \multirow{2}{*}{$\begin{array}{l}\text { TNN loss } \\
\left(\mathrm{kg} \mathrm{ha}^{-1}\right)\end{array}$} & \multicolumn{3}{|c|}{$\%$ in TNN loss } \\
\hline & & & & & $\mathrm{NN}_{\mathrm{O}}$ & $\mathrm{NN}_{\mathrm{I}}$ & $\mathrm{NN}_{\mathrm{S}}$ \\
\hline \multicolumn{8}{|c|}{14 May 2003} \\
\hline Station No. 6 & 2495 & $44.8(21.4)$ & 1.11 & 0.34 & 12.0 & 1.9 & 86.1 \\
\hline Station No. 4 & 79865 & $7.3(23.1)$ & 5.41 & 1.51 & 24.7 & 5.3 & 70.0 \\
\hline \multicolumn{8}{|c|}{12 May 2004} \\
\hline Station No. 6 & 4187 & $29.0(6.4)$ & 1.61 & 0.48 & 10.6 & 3.1 & 86.3 \\
\hline Station No. 4 & 67365 & $5.7(46.7)$ & 4.51 & 2.40 & 17.5 & 14.6 & 67.8 \\
\hline
\end{tabular}

* Data in the brackets are the uncertainty of the data estimated by mixing model at the flow peak.

through subsurface lateral flow accounted for about $86 \%$ of total $\mathrm{NO}_{3}^{-}-\mathrm{N}$ export at Station No. 6 and for about $68 \%$ at Station No. 4 (Table 3).

\section{Discussion}

The study catchment provided a unique feature that the sources and transport mechanisms of nutrients in stream could be identified from plot, hillslope to catchment scales. The geology and annual stream hydrology demonstrated a negligible influence of persistent groundwater within the 

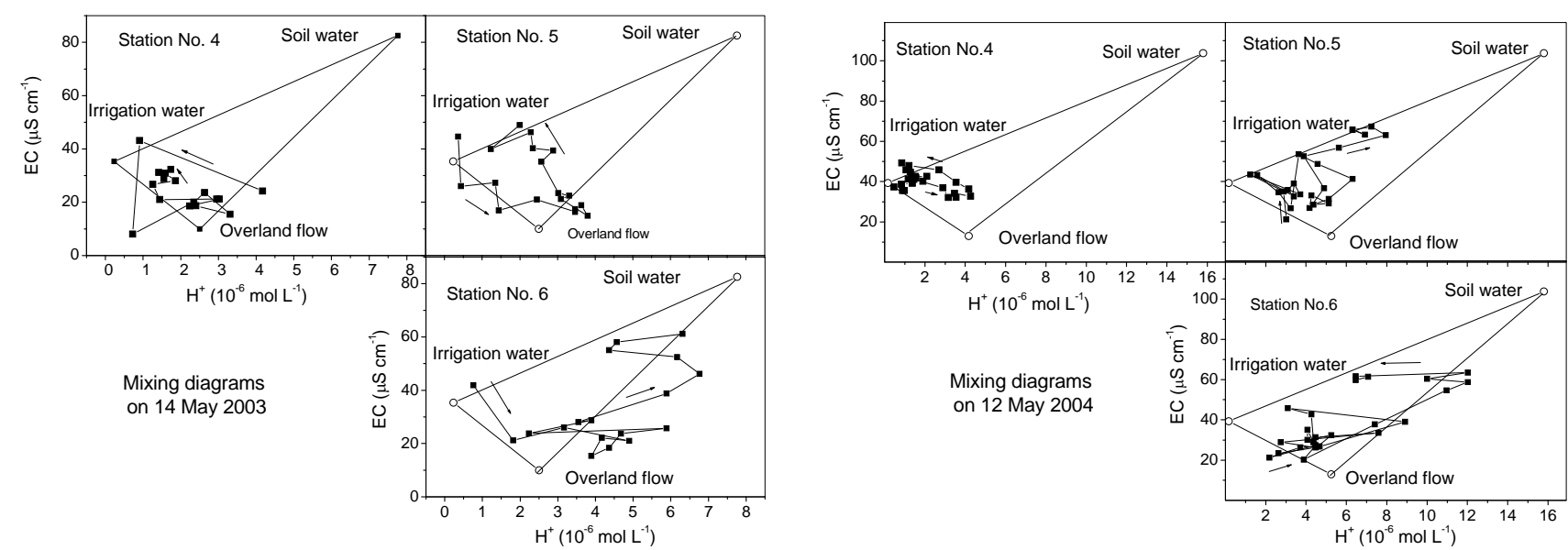

Fig. 6. Mixing diagrams showing stream water evolution indicated by $\mathrm{H}^{+}$concentration and electricity conductivity (EC) in the streams at the catchment outlet (Station No. 4) and at the inlet (Stations No. 5) and outlet (Station No. 6) of the subcatchment for the 14 May 2003 (left panel) and the 12 May 2004 (right panel) storm events. The arrows show the time sequence of water sampling.
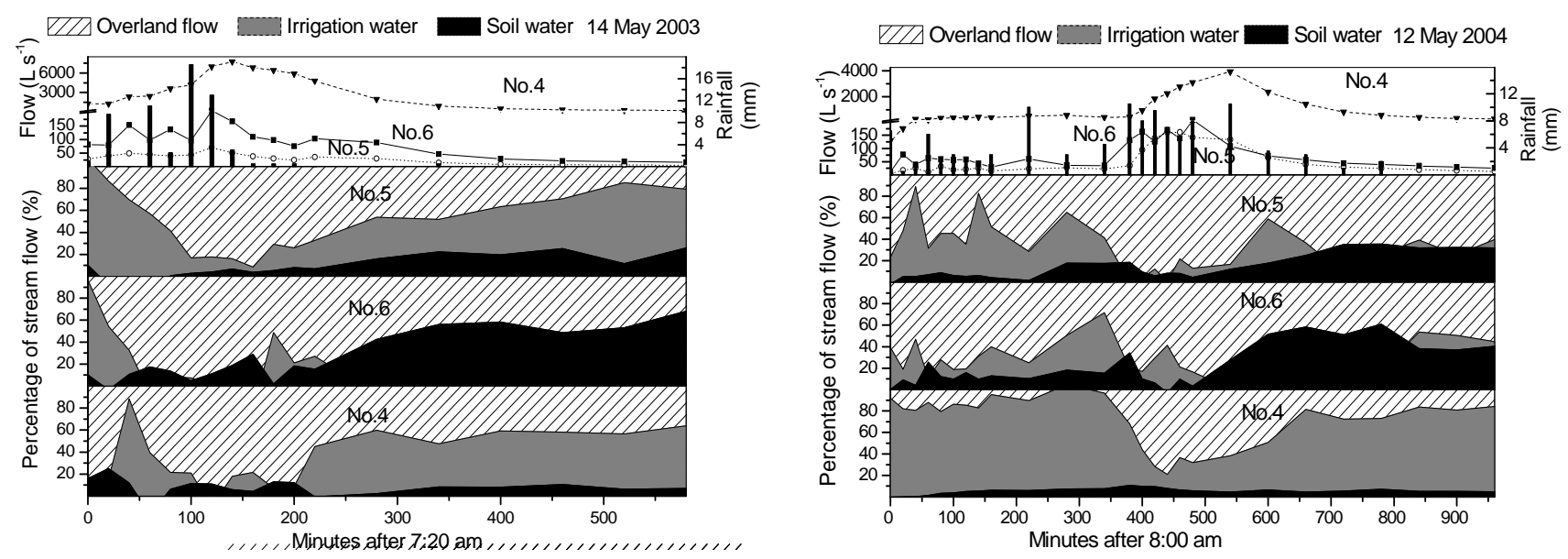

Fig. 7. Rainfall and flow components predicted by the chemical mixing model in the streams at the catchment outlet (Station No. 4) and at the inlet (Stations No. 5) and outlet (Station No. 6) of the subcatchment for the 14 May 2003 (upper) and 12 May 2004 (down) storm events.

catchment (Tang et al., 2007, 2008). Trenched irrigation channels right below the cropped hillslope made it possible to compare simultaneously the hillslope soil hydrology to the stream responses unimpeded by riparian zone. Such in situ natural experimental design was also applied to study the hydrological controls on dissolved organic matter and $\mathrm{N}$ fluxes from hillslopes in a small forestry watershed (van Verseveld et al., 2009). This study underscored the importance of subsurface lateral flow from the cropped hillslopes in transporting nutrients to surface stream in an intensive agricultural catchment in the low hilly region of subtropical China.

\subsection{Generation of subsurface lateral flow from hillslopes}

The spatial and temporal dynamics of soil water potential demonstrated that soil water saturation and drainage processes occurred in the deep soil layers under the two adjacent land uses in both storm events although the magnitudes of these dynamics varied between the two land uses (Figs. 2 and 3). During the observation periods, the soil water potential was always negative in the surface soil (above $0.40 \mathrm{~m}$ depth) and became positive at the deep soil depths (from 0.60 to $1.50 \mathrm{~m}$ ) particularly at the lower slope positions. Similar results have been observed in a forested shale hill catchment (Lin and Zhou, 2008), at a forested hillslope in the Austrian Alps (van Schaik et al., 2008) and in a semiarid region (Spanish Dehesas) (Wienhöfer et al., 2009). This has been attributed to the preferential flow through macropores in the surface soil and soil pipes in the subsoil. After the end of rainfall during the two storms, the saturation water table over the $1.5 \mathrm{~m}$ soil depth at the lower slope position reached to the 0.15 and $0.37 \mathrm{~m}$ depths on the chestnut 


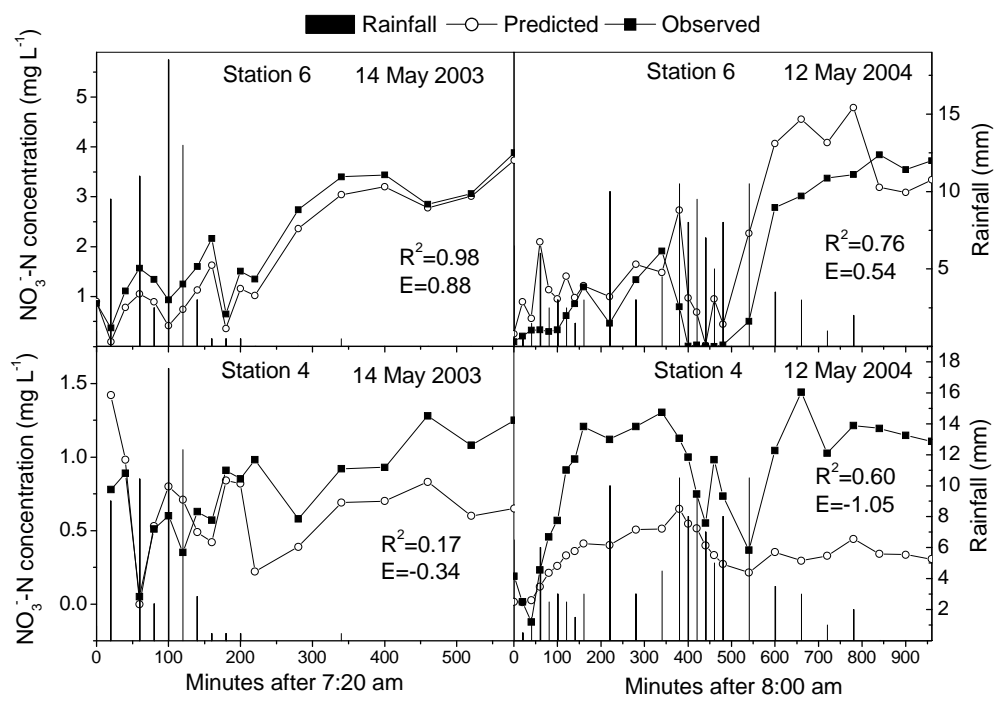

Fig. 8. $\mathrm{NO}_{3}^{-}$-N concentration observed and predicted by the chemical mixing model using $\mathrm{H}^{+}$concentration and $\mathrm{EC}$ in the streams at the subcatchment outlet (Station No. 6) and catchment outlet (Station No. 4) for the 14 May 2003 and 12 May 2004 storm events, E is the Nash-Sutcliff index.

hillslope and to the 0.74 and $1.00 \mathrm{~m}$ depths on the peanut cropping hillslope. Because there is no persistent groundwater in this study catchment and the tensiometers were installed far above the streams and ponds, the large domain of saturation water along the soil pedons on the hillslopes can be attributed to the large amount of rainfall (125 and $178 \mathrm{~mm})$ during the rainy season in the subtropics.

The rise and decline of saturation water table at the lower slope after the end of rainfall can only be explained by the generation of subsurface lateral flow from the upper slope and the drainage of the subsurface lateral flow out of the slopes. Subsurface lateral flow on steep and wet hillslopes is often through discrete soil pipes or macropores and most prevalently at the soil bedrock interface or above impeding layers (Sidle and Noguchi, 2001; Uchida et al., 2005; Trompvan Meerveld and McDonnell, 2006). There were large differences in saturated hydraulic conductivity between the surface soil ( 1.98 to $\left.3.60 \mathrm{~m} \mathrm{day}^{-1}\right)$ and in the deep soil ( 0.08 to $0.70 \mathrm{~m} \mathrm{day}^{-1}$ ) (Table 1 ). The difference in hydraulic conductivity between adjacent soil depths can change water flow from vertical to lateral direction (Lin, 2006). In addition, hillslope scale hydraulic connectivity allows the shift from vertical to lateral flow to happen, causing widespread lateral flow along the hillslope (McNamara et al., 2005). The saturation water table reaching to the subsurface soil that had larger hydraulic conductivity than the deep soil, may facilitate the generation of subsurface lateral flow (Bishop et al., 2004). The decline of saturation water table demonstrated that "old water" was propelled out over the deep soil layer (Petry et al., 2002). "Old water" is often characterized by the average soil water chemistry prior to a storm event concerned, while "new water", the infiltrated water during the storm event, has often different water chemistry from the old water (Chandler and Bisogni, 1999; Petry et al., 2002). This is indicated by the increased nitrate and potassium concentration and EC on the decreasing limbs of the hydrographs after the storms. The running spring between Stations No. 5 and No. 6 and the response of stream flow in the trenched stream indicated that both discrete and prevalent subsurface lateral flow generated from the cropped hillslopes in the study catchment.

The time lag of peak soil water potential at the $1.5 \mathrm{~m}$ behind the maximum rainfall intensity indicated the residence time of saturation water table. It varied with rainfall and soil profile characteristics. The longer time lag on 12 May 2004 ( 250 to $400 \mathrm{~min}$ ) than on 14 May 2003 (100 to $120 \mathrm{~min}$ ), and on the peanut hillslope (120 and $400 \mathrm{~min}$ ) than on the chestnut hillslope (100 and $250 \mathrm{~min}$ ) suggested that saturated soil water was retained for a longer time during the long-lasting storm events and in the soil profiles with more clay textured soil. The higher saturation water table over the $1.5 \mathrm{~m}$ soil depth on the chestnut hillslope than on the peanut cropping hillslope ( 1.13 to $1.35 \mathrm{~m}$ vs. 0.54 to $0.76 \mathrm{~m}$ ) indicated that the chestnut hillslope retained more water and would generate faster subsurface lateral flow due to its coarser texture than the peanut hillslope. Lin and Zhou (2008) also demonstrated that soil profile features such as soil horizon depths and landform positions influences on generation of subsurface lateral flow.

The landform and soil profile characteristics were similar between the peanut cropping hillslopes within the catchment. We detected similar soil water chemistry at different places under the peanut cropping system as the fertilization schedule was similar. We, then, assumed that the soil water movement as well as soil chemistry was similar between the above mentioned peanut cropping hillslopes. The decrease in positive soil water potential over the $1.5 \mathrm{~m}$ soil depth after 
the end of rainfall (Figs. 2 and 3) corresponded well to the first break point on the delayed flow recession curves in both the trenched stream and at the catchment outlet after the end of rainfall (Figs. 4 and 5), although the monitored sites were not directly connected. This confirmed that the subsurface lateral flow was quickly generated from the peanut hillslope and flowed to the streams through the catchment during the storms. The flush time lag behind the maximum rainfall intensity or peak flow can be attributed to the residence time of subsurface lateral flow moving from the upper slope to the lower slope (Soulsby et al., 2003). The same time lag (around $100 \mathrm{~min}$ ) at Stations No. 5 and 6 indicated that there was no interference for the subsurface lateral flow to directly discharge into the trenched channel below the peanut hillslope during the storms.

\subsection{Nutrient delivery pathways to the streams at the hillslope and catchment scale}

This study catchment was very intensively used for cropping. According to the regular sampling (Table 1) and the intensive sampling (Figs. 4 and 5), the concentrations of $\mathrm{N}$ were generally higher, but the concentrations of $\mathrm{P}$ in streams were generally lower than the most of those reported in the literature for agricultural (e.g. Jiang et al., 2010), forestry (e.g. van Verseveld et al., 2009) or pasture (Holz, 2010) catchment. These can be attributed to high application rates of $\mathrm{N}$ fertilizers, ranging from $218 \mathrm{~kg} \mathrm{~N} \mathrm{ha}^{-1} \mathrm{a}^{-1}$ to $71 \mathrm{~kg} \mathrm{Pha}^{-1} \mathrm{a}^{-1}$ (Tang et al., 2008) and to the soils that have high content of iron oxides ranging from 60 to $65 \mathrm{~g} \mathrm{~kg}^{-1}$ (Zhang and Horn, 2001). Phosphorus fixed with iron oxides will reduce its mobility.

The hydrographs and the chemographs of particulate $\mathrm{N}$ and $\mathrm{P}$ and suspended sediment were similar during the two storms (Figs. 4 and 5), showing increased concentrations with increasing rainfall intensity and the peak concentrations before the peak flows at all the stations except for Station No. 4 on the 14 May 2003 storm event (Fig. 4). These relationships have been widely reported in the literature (Holz, 2010; Nadal-Romero et al., 2008; Williams, 1989), but explained variously (e.g. Steinheimer et al., 1998; Seeger et al., 2004; Holz, 2010). The dominance of particulate $\mathrm{N}$ and $\mathrm{P}$ in total $\mathrm{N}$ and $\mathrm{P}$ (over $90 \%$ and about $100 \%$ respectively) suggests that overland flow controlled the delivery of particulate nutrients together with suspended sediments from the hillslope to the trenched stream. The time of peaks in the particulate nutrient concentrations before the peak flow in the trenched stream indicates flushing effects of overland flow (Boyer et al., 1997). Overland flow after the maximum rainfall intensity can be less effective in mixing with soil, releasing and transporting particulate nutrients on the hillslope, but continues to issue into the stream from the upper slope.

The rainfall characteristics explain the time differences between the peak particulate nutrient concentration and the peak flow. The storm on 14 May 2003 had intensive rainfall while the storm on 12 May 2004 had a long-lasting and low intensity rainfall although the amount of rainfall was similar (Fig. 5). This resulted in a large difference in peak flow at the catchment outlet (Station No. 4) (7751 vs. $39361 \mathrm{~s}^{-1}$ ), but little difference in peak flow in the trenched stream (Station No. 6) (215 vs. $\left.211 \mathrm{~s} \mathrm{~s}^{-1}\right)$. The difference in stream flow at the different stations suggests the contribution of other source of flows during the storm event on 14 May 2003 and the sources are possibly from other water sources such as the paddy fields. The long-lasting stream flow may lead to a longer time of peak particulate nutrient concentration prior to the peak flow during the storm event on 12 May 2004 than on 14 May 2003, while the strong stream can transport particulates for a longer distance, resulting in the time lag of particulate nutrient concentration behind the peak flow at Station No. 4 during the storm event on 14 May 2003.

The relationship between the dynamics of $\mathrm{NO}_{3}^{-}-\mathrm{N}$ concentration and stream flow were also similar during the two rainstorms at all the stations (Figs. 4 and 5). The $\mathrm{NO}_{3}^{-}-\mathrm{N}$ concentration did not response to high stream flow during the rainfall and increased on the recession limbs of hydrographs after the end of rainfall. On the 12 May 2004 storm event, the $\mathrm{NO}_{3}^{-}-\mathrm{N}$ concentration was relative high during the span of low rainfall intensity or low overland flow (Fig. 5), this giving a time for the interaction between overland flow and soil. The different responses of $\mathrm{NO}_{3}^{-}-\mathrm{N}$ concentration during and after the end of storm are consistent with many studies (e.g. Ocampo et al., 2006; Rusjan et al., 2008; Holz, 2010), but contradictory with others (Rusjan et al., 2008; van Verseveld et al., 2009; Jiang et al., 2010). The dynamics of labile nutrient concentration is commonly attributed to the "flushing" hypothesis (Anderson and Burt, 1982; Hornberger et al., 1994). The flushing mechanisms have been studied from hillslope scale to catchment scale (e.g. Ocampo et al., 2006; Weiler and McDonnell, 2006) and attributed to the hydrological controls, e.g. quantity of lateral flow from event water or groundwater, and the biogeochemical controls, e.g. availability and quantity of labile nutrients in the pathways. Nitrate concentrations in the streams were low during the rainfall period and increased through the recessing limb after the end of rainfall during the observed two storms. In the acidic soils, $\mathrm{NO}_{3}^{-}-\mathrm{N}$ is weakly sorbed and slowly transformed (Kemmitt et al., 2005) and can be leached and accumulated at deep soil layers (Vazquez et al., 2006). Our previous study on the same peanut hillslope reported that the average $\mathrm{NO}_{3}^{-}$$\mathrm{N}$ concentration in soil water was lower in the surface soil $(0-0.40 \mathrm{~m})$ than in the deep soil $(0.85 \mathrm{~m})$ on both upper and lower slope positions $\left(0.6-2.3\right.$ vs. $\left.4.3-7.6 \mathrm{mg} \mathrm{l}^{-1}\right)$, and at all the soil depths on the lower slope than on the upper slope (1.9 vs. $4.2 \mathrm{mgl}^{-1}$ ) (Wang et al., 2011). The low $\mathrm{NO}_{3}^{-}-\mathrm{N}$ concentration in the surface soil water and the dilution effect of overland flow may explain the stable and low $\mathrm{NO}_{3}^{-}-\mathrm{N}$ concentration in the stream flow during the rainfall period. The simultaneous happening of the increase in $\mathrm{NO}_{3}^{-}-\mathrm{N}$ concentration in the stream flow and the decrease in soil water potential at the $1.5 \mathrm{~m}$ soil depth at the lower slope positions 
confirm that the subsurface lateral flow generate along the slope propelled and displace the nitrate enriched "old soil water" through the deep soil pedon (Chandler and Bisogni, 1999; Hooper et al., 1990; Petry et al., 2002). The relative low $\mathrm{NO}_{3}^{-}-\mathrm{N}$ concentration $\left(1.39 \mathrm{mg}^{-1}\right)$ in the spring water as compared with soil water and well water (Table 2) may be attributed possibly to denitrification process which may occur through the long slope.

\subsection{Contribution to nutrient loading through subsurface lateral flow}

In this catchment, possible water sources were direct rainwater, irrigation water via channels and soil waters. The fouryear regular and intensive monitoring showed that the water sources of irrigation water, soil water and overland water were distinct in $\mathrm{H}^{+}$concentration and EC (Table 2, Fig. 6). The chemistry of overland flow generated during the rainfall events was similar to the rainwater (Table 2) and the overland flow was representative of local surface sources of stream flow with lower $\mathrm{pH}$ values. Thus, we chose irrigation water, soil water and overland water as potential end members of mixing models in this catchment. The two parameters, $\mathrm{H}^{+}$ concentration and EC, were used to establish a chemical mixing model for hydrograph separation. There are many studies using $\mathrm{H}^{+}$concentration (Raiswell, 1984; Neal and Christophersen, 1989; Jarvie et al., 2001) and electrical conductivity (EC) (e.g. Nakamura, 1971; Pilgrim et al., 1979; O’Brien and Hendershot, 1993; Durand and Torres, 1996) in chemical mixing model. There are also some studies that have successfully used $\mathrm{NO}_{3}^{-}-\mathrm{N}$ concentration in chemical mixing model (Soulsby et al., 2003; Tiemeyer et al., 2008). $\mathrm{H}^{+}$concentration has been successfully used particularly for acidic catchments as the biogeochemical process is generally low (Raiswell, 1984; Neal and Christophersen, 1989) and for episodic high flow events in which variations in $\mathrm{pH}$ are associated with different hydrological pathways (Jarvie et al., 2001). Although $\mathrm{NO}_{3}^{-}-\mathrm{N}$ is known to be subjected to biogeochemical transformations and non-conservative during a relatively long period, it is often assumed conservative during a relatively short storm period (Durand and Torres, 1996). Because of the significant correlation between EC value and $\mathrm{NO}_{3}^{-}-\mathrm{N}$ concentration $(\mathrm{P}<0.01)$ and easier measurement for $\mathrm{EC}$ than for $\mathrm{NO}_{3}^{-}-\mathrm{N}$ concentration, $\mathrm{EC}$ instead of $\mathrm{NO}_{3}^{-}-\mathrm{N}$ concentration was used in the chemical mixing model.

The mixing model using $\mathrm{H}^{+}$and $\mathrm{EC}$ value gave reasonable goodness between the predicted and observed $\mathrm{NO}_{3}^{-}-\mathrm{N}$ concentrations particularly at the hillslope scale (Station No. 6), with the determination coefficient $\left(R^{2}\right)$ ranging from 0.76 to 0.98 and the Nash-Sutcliffe model efficiency $(E)$ ranging from 0.54 to 0.88 (Fig. 8). These disagreements are attributed to the uncertainty of the subsurface lateral flow, mainly raised by the chemical mixing modeling using two simple parameters $\left(\mathrm{H}^{+}\right.$and EC) (Table 3), due to contribution of other water sources into the stream at the catchment scale (Station
No. 4) than at the hillslope scale (Station No. 6) (Fig. 8) and to higher precedent soil water content and the long-lasting rainfall on the 12 May 2004 event than on the 14 May 2003 event. The water sources include overland flow or subsurface flow generated from the paddy field, which contains less $\mathrm{NO}_{3}^{-}-\mathrm{N}$ concentration than that from the hillslopes (Tang et al., 2008). Lateral subsurface flow through paddy bunds was identified using dye tracing in this study catchment (Janssen and Lennartz, 2008, 2009). The higher precedent soil water content and the long-lasting rainfall on the 12 May 2004 event resulted in a large proportion of subsurface lateral flow at the beginning of rainfall.

Although overland flow was the major pathway for particulate $\mathrm{N}$ and $\mathrm{P}$ export during the rainfall periods, subsurface flow was the dominant pathway for $\mathrm{NO}_{3}^{-}-\mathrm{N}$ export (Table 3 ). The chemical mixing model demonstrated that the subsurface lateral flow accounted for $29 \%$ to $45 \%$ of total flow in the trenched stream and exported 1.5 to $2.4 \mathrm{~kg} \mathrm{Nha}^{-1}$ of $\mathrm{NO}_{3}^{-}-\mathrm{N}$ (or $86 \%$ of total $\mathrm{NO}_{3}^{-}-\mathrm{N}$ loss or $26 \%$ of total $\mathrm{N}$ loss) from the peanut cropping hillslope during the intensive rainstorm events. Such rainstorm events with daily rainfall over $100 \mathrm{~mm}$ occurred 4 to 8 times a year in the region, suggesting the importance of subsurface lateral flow in nutrient delivery to surface water in the study region. There are few studies attempting to estimate subsurface lateral flow from hillslopes in agricultural catchment. Using hydrograph separation, Soulsby et al. (2003) reported that subsurface lateral flow accounted for $10 \%$ to $52 \%$ of total stream flow during storm from a grazing catchment in Scotland, which has widely spread and well drained alluvium and gravels within soil. Wang et al. (2011), applying the model Hydrus 2-D, demonstrated that the subsurface lateral flow from the peanut cropping hillslope in the same study catchment accounted for $35 \%$ to $42 \%$ of annual rainfall and exports 45 to $64 \mathrm{~kg} \mathrm{~N} \mathrm{ha}^{-1} \mathrm{a}^{-1}$ out of the soil pedon into the streams, which was larger than total $\mathrm{N}$ from the overland flow (6 to $6.9 \mathrm{~kg} \mathrm{ha}^{-1} \mathrm{a}^{-1}$ ). The lower proportion of subsurface lateral flow from the catchment outlet is explained by the contribution of the water sources from the paddy fields.

This study highlights the significance of controlling subsurface lateral flow from hillslopes in agricultural catchment. Heavy rainfall can penetrate the surface soil through macropores and saturate the deep soil over impermeable soil layers, resulting in the generation of quick subsurface lateral flow during and after storms. Excess $\mathrm{N}$ fertilizers can be transformed into $\mathrm{NO}_{3}^{-}-\mathrm{N}$ and leached into deep soil (Vazquez et al., 2006). If $\mathrm{NO}_{3}^{-}-\mathrm{N}$ in the deep soil can not be promptly used by plants due to limited root depth, it will be intercepted and transported into streams by subsurface lateral flow (Steinheimer et al., 1998; Royer et al., 2006). This will then result in larger-scale water quality issues. Many best management practices with attempts to control soil and water erosion are effective in controlling the flush of nutrients mainly in particulate forms on the rising limbs of stream flow, 
but may not be effective in controlling the flush of soluble nutrients on the recession limbs of stream flow. Therefore, new strategies have to reduce $\mathrm{NO}_{3}^{-} \mathrm{N}$ leaching and accumulation in deep soil and its transport through subsurface lateral flow. These strategies may be carried out by optimization of timing and doze of chemical fertilization to reduce $\mathrm{N}$ leaching or by adopting deep-root crops as in agroforestry system (Wang et al., 2011) or buffering strips to intercept subsurface lateral flow and leached N (Song et al., 2010; Nair, 2011).

\section{Conclusions}

Simultaneous monitoring hillslope soil hydrology and stream hydrochemographs underscored the importance of subsurface lateral flow in transporting nitrate from gentle hillslope to surface waters in agricultural catchment in the subtropical climate. The spatial and temporal dynamics of soil water potential demonstrated preferential flow in the surface soil and soil water saturation and drainage process over the impermeable deep soil layers ( 0.6 to $1.5 \mathrm{~m}$ depth) irrespective of land uses during the intensive rainstorms. After the end of rainfall, the stream flow corresponded well to the decrease in positive soil water potential over the $1.5 \mathrm{~m}$ depth on the lower hillslope position. These gave direct evidences of the generation of fast subsurface lateral flow along the hydraulic stratified soil pedons during intensive rainstorm. The positive correlation between particulate $\mathrm{N}$ and $\mathrm{P}$ concentrations and stream flow demonstrated that the overland flow was the dominant pathway during the rainfall. The negative correlation between nitrate concentration and stream flow suggested that the subsurface lateral flow was the dominant pathway after the end of rainfall and that the subsurface flow expelled nitrate leached and accumulated in the deep soils. The chemical mixing model based on $\mathrm{EC}$ and $\mathrm{H}^{+}$concentration showed that the subsurface lateral flow during the rainstorm events accounted for $29 \%$ to $45 \%$ of the stream flow and about $86 \%$ of total $\mathrm{NO}_{3}^{-}-\mathrm{N}$ loss (or $26 \%$ of total $\mathrm{N}$ loss) from the peanut cropping hillslope and for $5.7 \%$ to $7.3 \%$ of the stream flow about $69 \%$ of total $\mathrm{NO}_{3}^{-}-\mathrm{N}$ loss (or $28 \%$ of total $\mathrm{N}$ loss) at the catchment outlet. The uncertainty of the modeling was large at the catchment outlet and needs further study with new models. This study implies that best management practices controlling non-point source pollution from agricultural catchment have to be effective in controlling overland flow, but also in controlling nutrient leaching and subsurface lateral flow particularly in the areas with frequent heavy rainstorm precipitation and great soil infiltration.
Acknowledgements. This work was funded partly by NSFC (Grant No. 40701071 and 40801101), DFG (Grant No. ZE 254/4) and EC-FP7 (SoilTrEC, Grant No. 244118). The authors acknowledge the contributions from M. Z. Wang, A. Thimm, Y. S. Jing and X. Q. Cheng in the field and the Ecological Experimental Research Station of Red Soil, CAS for supporting accommodation and facilities for the field work.

Edited by: M. Weiler

\section{References}

Allaire, S. E., Roulier, S., and Cessna, A. J.: Quantifying preferential flow in soils: A review of different techniques, J. Hydrol., 378, 179-204, 2009.

Anderson, M. G. and Burt, T. P.: The contribution of throughflow to storm runoff: an evaluation of a chemical mixing model, Earth Surf. Proc. Land., 33, 211-225, 1982.

Bishop, K., Seibert, J., Kohler, S., and Laudon, H.: Resolving the double paradox of rapidly mobilized old water with highly variable responses in runoff chemistry, Hydrol. Process., 18, 185189, 2004.

Boyer, E. W., Hornberger, G. M., Bencala, K. E., and McKnight, D. M.: Response characteristics of DOC flushing in an alpine catchment, Hydrol. Process., 11, 1635-1647, 1997.

Bronstert, A. and Plate, E. J.: Modelling of runoff generation and soil moisture dynamics for hillslopes and micro-catchments, J. Hydrol., 198, 177-195, 1997.

Burke, A. R. and Kasahara, T.: Subsurface lateral flow generation in aspen and conifer-dominated hillslopes of a first order catchment in northern Utah, Hydrol. Process., 25, 1407-1417, 2011.

Burns, D. A., McDonnell, J. J., Hooper, R. P., Peters, N. E., Freer, J. E., Kendall, C., and Beven, K.: Quantifying contributions to storm runoff through end-member mixing analysis and hydrologic measurements at the Panola Mountain Research Watershed (Georgia, USA), Hydrol. Process., 15, 1903-1924, 2001.

Chandler, D. G. and Bisogni, J. J.: The use of alkalinity as a conservative tracer in a study of near-surface hydrologic change in tropical karst, J. Hydrol., 216, 172-182, 1999.

Cirmo, C. P. and McDonnell, J. J.: Linking the hydrologic and biogeochemical controls of nitrogen transport in near-stream zones of temperate-forested catchments: a review, J. Hydrol., 199, 88120, 1997.

Cras, A., Marc, V., and Travi, Y.: Hydrological behaviour of subMediterranean alpine headwater streams in a badlands environment, J. Hydrol., 339, 130-144, 2007.

DeWalle, D. R., Swistock, B. R., and Sharpe, W. E.: Three component tracer model for stormflow on a small Appalachian forested catchment, J. Hydrol., 104, 301-310, 1988.

Duan, S. W., Zhang, S., and Huang, H. Y.: Transport of dissolved inorganic nitrogen from the major rivers to estuaries in China, Nutr. Cycl. Agroecosys., 57, 13-22, 2000.

Durand, P. and Torres, J. L. J.: Solute transfer in agricultural catchments: The interest and limits of mixing models, J. Hydrol., 181, 1-22, 1996.

Edwards, W. M. and Owens, L. B.: Large Storm Effects on Total Soil-Erosion, J. Soil Water Conserv., 46, 75-78, 1991. 
Garg, K. K., Jha, M. K., and Kar, S.: Field investigation of water movement and nitrate transport under perched water table conditions, Biosyst. Eng., 92, 69-84, 2005.

Genereux, D.: Quantifying uncertainty in tracer-based hydrograph separations, Water Resour. Res., 34, 915-919, 1998.

Hagedorn, F.: Transformation and transport of nitrogen in a subalpine catchment-effects of elevated nitrogen deposition, $\mathrm{PhD}$ thesis, ETH, Zurich, Switzerland, 1999.

Holz, G. K.: Sources and processes of contaminant loss from an intensively grazed catchment inferred from patterns in discharge and concentration of thirteen analytes using high intensity sampling, J. Hydrol., 383, 194-208, 2010.

Hooper, R. P., Christophersen, N., and Peters, N. E.: Modeling Streamwater Chemistry as a Mixture of Soilwater End-Members - an Application to the Panola Mountain Catchment, Georgia, USA, J. Hydrol., 116, 321-343, 1990.

Horn, R. and Smucker, A.: Structure formation and its consequences for gas and water transport in unsaturated arable and forest soils, Soil Till. Res., 82, 5-14, 2005.

Hornberger, G. M., Bencala, K. E., and McKnight, D. M.: Hydrological controls on dissolved organic carbon during snowmelt in the Snake River near Montezuma, Colorado, Biogeochemistry, 25, 147-165, 1994.

Hu, Zh. Y., Xu, Ch. K., Zhou, L. N., Sun, B. H., He, Y. Q., Zhou, J., and Cao, Zh. H.: Contribution of Atmospheric Nitrogen Compounds to N Deposition in a Broadleaf Forest of Southern China, Pedosphere, 17, 360-365, 2007.

Huang, W. Y., Wu, Y. G., and Shu, Y. J.: Hydrographical environmental problems and countermeasures of main lakes and reservoirs in China, J. Lake Sci., 16, 83-90, 1998.

Inamdar, S. P. and Mitchell, M. J.: Contributions of riparian and hillslope waters to storm runoff across multiple catchments and storm events in a glaciated forested watershed, J. Hydrol., 341, 116-0130, 2007.

Janssen, M. and Lennartz, B.: Characterization of preferential flow pathways through paddy bunds with dye tracer tests, Soil Sci. Soc. Am. J., 72, 1756-1766, 2008.

Janssen, M. and Lennartz, B.: Water losses through paddy bunds: Methods, experimental data, and simulation studies, J. Hydrol., 369, 142-153, 2009.

Jarvie, H. P., Neal, C., Smart, R., Owen, R., Fraser, D., Forbes, I., and Wade, A.: Use of continuous water quality records for hydrograph separation and to assess short-term variability and extremes in acidity and dissolved carbon dioxide for the River Dee, Scotland, Sci. Total Environ., 265, 85-98, 2001.

Jiang, R., Woli, K. P., Kuramochi, K., Hayakawa, A., Shimizu, M., and Hatano, R.: Hydrological process controls on nitrogen export during storm events in an agricultural watershed, Soil Sci. Plant Nutr., 56, 72-85, 2010.

Jing, Y. S., Zhang, B., Thimm, A., and Zepp, H.: Anisotropy of soil hydraulic properties along arable slopes, Pedosphere, 18, 353$362,2008$.

Kemmitt, S. J., Wright, D., and Jones, D. L.: Soil acidification used as a management strategy to reduce nitrate losses from agricultural land, Soil Biol. Biochem., 37, 867-875, 2005.

Khan, A. A. H. and Ong, C. K.: Design and calibration of tipping bucket system for field runoff and sediment quantification, J. Soil Water Conserv., 52, 437-443, 1997.
Kwong, K. F. N. K., Bholah, A., Volcy, L., and Pynee, K.: Nitrogen and phosphorus transport by surface runoff from a silty clay loam soil under sugarcane in the humid tropical environment of Mauritius, Agr. Ecosyst. Environ., 91, 147-157, 2002.

Lin, H.: Temporal stability of soil moisture spatial pattern and subsurface preferential flow pathways in the shale hills catchment, Vadose Zone J., 5, 317-340, 2006.

Lin, H. S. and Zhou, X. B.: Evidence of Subsurface Preferential Flow Using Soil Hydrologic Monitoring in the Shale Hills Catchment, Eur. J. Soil Sci., 59, 34-49, 2008.

Lin, H. S., Kogelmann, W., Walker, C., and Bruns, M. A.: Soil moisture patterns in a forested catchemnt: a hydropedological perspective, Geoderma, 131, 345-368, 2006.

Lo, L.: Gaussian error propagation applied to ecological data: Postice-storm-downed woody biomass, Ecol. Monogr., 75, 451-466, 2005.

Lowrance, R. R., Todd, R. L., and Asmussen, L. E.: Nutrient cycling in an agricultural watershed: Streamflow and artificial drainage, J. Environ. Qual., 13, 27-32, 1984.

Luxmoore, R. J.: On preferential flow and its measurement, paper presented at Preferential Flow Proceedings of The national Symposium, American Society of Agricultural Engineers, Chicago, Illinois, 16-17 December 1991.

McHale, M. R., McDonnell, J. J., Mitchell, M. J., and Cirmo, C. P.: A field-based study of soil water and groundwater nitrate release in an Adirondack forested watershed, Water Resour. Res., 38, 1031, doi:10.1029/2000WR000102, 2002.

McNamara, J. P., Chandler, D., Seyfriend, M., and Achet, S.: Soil moisture states, lateral flow, and streamflow generation in a semiarid, snow melt-driven catchment, Hydrol. Process., 19, 40234038, 2005.

Mohanty, B. P., Bowman, R. S., Hendrickx, J. M. H., Simunek, J., and Van Genuchten, M. T.: Preferential transport of nitrate to a tile drain in an intermittent-flood-irrigated field: Model development and experimental evaluation, Water Resour. Res., 34, 1061-1076, 1998.

Mualem, Y.: A new model for predicting the hydraulic conductivity of unsaturated porous media, Water Resour. Res., 12, 513-522, 1976.

Nadal-Romero, E., Regues, D., and Latron, J.: Relationships among rainfall, runoff, and suspended sediment in a small catchment with badlands, Catena, 74, 127-136, 2008.

Nair, P. K. R.: Agroforestry Systems and Environmental Quality: Introduction, J. Environ. Qual., 40, 784-790, 2011.

Nakamura, R.: Runoff analysis by electrical conductivity of water, J. Hydrol., 14, 197-212, 1971.

Nash, D. M. and Halliwell, D. J.: Fertiliser and phosphorus loss from productive grazing systems, Aust. J. Soil Res., 37, 403429, 1999.

Nash, J. E. and Sutcliffe, J. V.: River flow forecasting through conceptual models, Part 1: A discussion of principles, J. Hydrol., 10, 282-290, 1970.

Neal, C. and Christophersen, N.: Inorganic aluminium-hydrogen ion relationships for acidified streams; the role of water mixing processes, Sci. Total Environ., 80, 195-203, 1989.

Newman, B. D., Campbell, A. R., and Wilcox, B. P.: Lateral subsurface pathways in a semiarid ponderosa pine hillslope, Water Resour. Res., 34, 348-349, 1998. 
O'Brien, C. and Hendershot, W. H.: Separating streamflow into groundwater, solum and upwelling flow and its implication for hydrochemical modeling, J. Hydrol., 146, 1-12, 1993.

Ocampo, C. S., Oldham, C. E., Sivapalan, M., and Turner, J. V.: Hydrological versus biogeochemical controls on catchment nitrate export: a test of the flushing mechanism, Hydrol. Process., 20, 4269-4286, 2006.

Petry, J., Soulsby, C., Malcolm, I. A., and Youngson, A. F.: Hydrological controls on nutrient concentrations and fluxes in agricultural catchments, Sci. Total Environ., 294, 95-110, 2002.

Pilgrim, D. H., Huff, D. D., and Steele, T. D.: Use of specific conductance and contact time relations for separating flow components in storm runoff, Water Resour. Res., 15, 329-339, 1979.

Raiswell, R.: Chemical-Models of Solute Acquisition in Glacial Melt Waters, J. Glaciol., 30, 49-57, 1984.

Royer, T. V., David, M. B., and Gentry, L. E.: Timing of riverine export of nitrate and phosphorus from agricultural watersheds in Illinois: Implications for reducing nutrient loading to the Mississippi River, Environ. Sci. Technol., 40, 4126-4131, 2006.

Rusjan, S., Brilly, M., and Mikoš, M.: Flushing of nitrate from a forested watershed: an insight into hydrological nitrate mobilization mechanisms through seasonal highfrequency stream nitrate dynamics, J. Hydrol., 354, 187-202, 2008.

Schlichting, E. and Schweikle, V.: Interpedon Translocations and Soil Classification, Soil Sci., 130, 200-204, 1980.

Seeger, M., Errea, M. P., Begueria, S., Arnaez, J., Marti, C., and Garcia-Ruiz, J. M.: Catchment soil moisture and rainfall characteristics as determinant factors for discharge/suspended sediment hysteretic loops in a small headwater catchment in the Spanish pyrenees, J. Hydrol., 288, 299-311, 2004.

Sidle, R. C. and Noguchi, S.: Conceptual model of preferential flow systems in forested hillslopes: evidence of self organization, Hydrol. Proccess., 15, 1675-1692, 2001.

Sinaj, S., Stamm, C., Toor, G. S., Condron, L. M., Hendry, T., Di, H. J., Cameron, K. C., and Frossard E.: Phosphorus exchangeability and leaching losses from two grassland soils, J. Environ. Qual., 31, 319-330, 2002.

Song, K., Lee, S. H., Mitsch, W. J., and Kang, H.: Different responses of denitrification rates and denitrifying bacterial communities to hydrologic pulsing in created wetlands, Soil Biol. Biochem., 42, 1721-1727, 2010.

Soulsby, C., Petry, J., Brewer, M. J., Dunn, S. M., Ott, B., and Malcolm, I. A.: Identifying and assessing uncertainty in hydrological pathways: a novel approach to end member mixing in a Scottish agricultural catchment, J. Hydrol., 274, 109-128, 2003.

Stamm, C., Fluehler, H., Gaechter, R., Leuenberger, J., and Wunderli, H.: Preferential transport of phosphorus in drained grassland, J. Environ. Qual., 27, 515-522, 1998.

Steinheimer, T. R., Scoggin, K. D., and Kramer, L. A.: Agricultural chemical movement through a field size watershed in Iowa: Surface hydrology and nitrate losses in discharge, Environ. Sci. Technol., 32, 1048-1052, 1998.

Tang, J. L., Zhang, B., and Zepp, H.: Estimation of irrigation flow by hydrograph analysis in a complex agricultural catchment in subtropical China, Hydrol. Process., 21, 1280-1288, 2007.

Tang, J. L., Zhang, B., Gao, C., and Zepp, H.: Hydrological pathway and source area of nutrient losses identified by a multi-scale monitoring in an agricultural catchment, Catena, 72, 374-385, 2008.
Tiemeyer, B., Lennartz, B., and Kahle, P.: Analysing nitrate losses from an artificially drained lowland catchment (North-Eastern Germany) with a mixing model, J. Hydrol., 116, 1-4, 2008.

Tromp-van Meerveld, H. J., and McDonnell, J. J.: Threshold relations in subsurface stormflow: 1. A 147-storm analysis of the Panola hillslope, Water Resour. Res., 42, W02410, doi:10.1029/2004WR003778, 2006.

Tromp-van Meerveld, H. J., Peters, N. E., and McDonnell, J. J.: Effect of bedrock permeability on subsurface stormflow and the water balance of a trenched hillslope at the Panola Mountain Research Watershed, Georgia, USA, Hydrol. Process., 21, 750-769, 2007.

Uchida, T., Tromp-van Meerveld, I., and McDonnell, J. J.: The role of lateral pipe flow in hillslope runoff response: an intercomparison of non-linear hillslope response, J. Hydrol., 311, 117-133, 2005.

USEPA: Environmental indicators of water quality in the United States, U.S. Gov. Print. Office, Washington, DC, 1996.

van Der Velde, Y., De Rooij, G. H., Rozemeijer, J. C., van Geer, F. C., and Broers, H. P.: Nitrate response of a lowland catchment: On the relation between stream concentration and travel time distribution dynamics, Water Resour. Res., 46, W11534, doi:10.1029/2010wr009105, 2010.

van Genuchten, M. Th.: A closed -form equation for predicting the hydraulic conductivity of unsaturated soils, Soil Sci. Soc. Am. J., 44, 892-898, 1980.

van Schaik, N., Schnabel, S., and Jetten, V. G.: The influence of preferential flow on hillslope hydrology in a semi-arid watershed (in the Spanish Dehesas), Hydrol. Process., 22, 3844-3855, doi:10.1002/hyp.6998, 2008.

van Verseveld, W. J., McDonnell, J. J., and Lajth, K.: The role of hillslope hydrology in controlling nutrient loss, J. Hydrol., 367, 177-187, 2009.

Vazquez, N., Pardo, A., Suso, M. L., and Quemada, M.: Drainage and nitrate leaching under processing tomato growth with drip irrigation and plastic mulching, Agr. Ecosyst. Environ., 112, 313 323, 2006.

Wang, Y., Lin, L., Zhang, B., and Zepp, H.: Agroforestry system reduces nitrate loss through subsurface interflow in subtropical China, Agr. Ecosyst. Environ., 140, 441-453. 2011.

Weiler, M. and McDonnell, J. J.: Testing nutrient flushing hypotheses at the hillslope scale: A virtual experiment approach, J. Hydrol., 319, 339-356, 2006.

Wessolek, G., Plagge, R., Leij, F. J., and van Genuchten, M. Th.: 1994 Analysing problems in describing field and laboratory measured soi1 hydraulic properties, Geoderma, 64, 93-110, 1994.

Wienhöfer, J., Germer, K., Lindenmaier, F., Färber, A., and Zehe, E.: Applied tracers for the observation of subsurface stormflow at the hillslope scale, Hydrol. Earth Syst. Sci., 13, 1145-1161, doi:10.5194/hess-13-1145-2009, 2009.

Williams, G. P.: Sediment concentration versus water discharge during single hydrologic events in rivers, J. Hydrol., 111, 89106, 1989.

Wu, C. H., Maurer, C., Wang, Y., Xue, S. Z., and Davis, D. L.: Water Pollution and Human Health in China, Environ, Health Persp., 107, 251-256, 1999.

Xu, R. K., Zhao, A. Z., Li, Q. M., Kong, X. L., and Ji, G. L.: Acidity regime of the Red Soils in a subtropical region of southern China under field conditions, Geoderma, 115, 75-84, 2003. 
Zehe, E. and Blöschl, G.: Predictability of hydrologic response at the plot and catchment scales: Role of initial conditions, Water Resour. Res., 40, doi:10.1029/2003WR002869, 2004.

Zehe, E. and Fluhler, H.: Preferential transport of isoproturon at a plot scale and a field scale tile-drained site, J. Hydrol., 247, 100-115, 2001.

Zepp, H., Tang, J. L., and Zhang, B.: Methodological framework for a multi-scale study on hydrological processes and soil erosion in subtropical southeast China, Pedosphere, 15, 695-706, 2005.

Zhang, B. and Horn, R.: Mechanisms of aggregate stabilization in Ultisols from subtropical China, Geoderma, 99, 123-145, 2001.

Zhang, W. L., Xu, A. G., Ji, H. J., and Kolbe, H.: Estimation of agricultural non-point source pollution in China and the alleviating strategies, Sci. Agr. Sinica, 37, 1018-1026, 2004.
Zhou, J. M., Chen, X. Q., Xie, J. C., and Hardter, R.: Nutrient balance and nutrient management in agro-ecosystems of China, in: Nutrient management in China - Part 1, Nutrient balances and nutrient cycling in agro-ecosystems, edited by: Hardter, R., Xie, J. C., Zhou, J. M., IPI, Basel, Switzerland, 41-54, 2004.

Zhu, Q. and Lin, H. S.: Simulation and validation of concentrated subsurface lateral flow paths in an agricultural landscape, Hydrol. Earth Syst. Sci., 13, 1503-1518, doi:10.5194/hess-13-15032009, 2009.

Zhu, Z. L. and Chen, D. L.: Nitrogen fertilizer use in China - Contributions to food production, impacts on the environment and best management strategies, Nutr. Cycl. Agroecosys., 63, 117127, 2002. 